NBER WORKING PAPER SERIES

\title{
ESTIMATING THE ECONOMIC IMPACTS OF LIVING WAGE MANDATES USING EX ANTE SIMULATIONS, LONGITUDINAL ESTIMATES, AND NEW PUBLIC AND ADMINISTRATIVE DATA: \\ EVIDENCE FOR NEW YORK CITY
}

\author{
David Neumark \\ Matthew Thompson \\ Francesco Brindisi \\ Leslie Koyle \\ Clayton Reck \\ Working Paper 18055 \\ http://www.nber.org/papers/w18055
}

\author{
NATIONAL BUREAU OF ECONOMIC RESEARCH \\ 1050 Massachusetts Avenue \\ Cambridge, MA 02138 \\ May 2012
}

This paper is drawn from a larger study conducted by Charles Rivers Associates, funded by the New York City Economic Development Corporation (Charles Rivers Associates, 2011). The views expressed are those of the authors and do not reflect the views of Charles River Associates, the City of New York, its Office of Management and Budget, the New York City Economic Development Corporation, or the National Bureau of Economic Research. We are grateful to Daniel Hamermesh for many helpful comments and to Marsha Courchane, Timothy Riddiough, and Anthony Yezer for collaboration on the larger project.

At least one co-author has disclosed a financial relationship of potential relevance for this research. Further information is available online at http://www.nber.org/papers/w18055.ack

NBER working papers are circulated for discussion and comment purposes. They have not been peerreviewed or been subject to the review by the NBER Board of Directors that accompanies official NBER publications.

(C) 2012 by David Neumark, Matthew Thompson, Francesco Brindisi, Leslie Koyle, and Clayton Reck. All rights reserved. Short sections of text, not to exceed two paragraphs, may be quoted without explicit permission provided that full credit, including $(\subset$ notice, is given to the source. 
Estimating the Economic Impacts of Living Wage Mandates Using Ex Ante Simulations, Longitudinal Estimates, and New Public and Administrative Data: Evidence for New York City

David Neumark, Matthew Thompson, Francesco Brindisi, Leslie Koyle, and Clayton Reck NBER Working Paper No. 18055

May 2012

JEL No. J18,J23,J38

\title{
$\underline{\text { ABSTRACT }}$
}

Policy researchers often have to estimate the future effect of imposing a policy in a particular location. There is often historical information on the effects of similar policies in other jurisdictions, but no information on the effects of the policy in the jurisdiction in question, and the policy may have specific features not reflected in the experiences of other areas. It is then necessary to combine the historical evidence from other locations with information and data specific to the jurisdiction in question. In this paper, we illustrate and use this approach in estimating the impact of a proposed living wage mandate for New York City. We explain how we combined elements of "ex ante" evaluations of living wage laws with before-and-after (longitudinal) estimates of the effects of living wage laws. We also incorporate detailed location-specific information on workers, families, and employers using administrative data and other new public data sources.

\author{
David Neumark \\ Department of Economics \\ University of California at Irvine \\ 3151 Social Science Plaza \\ Irvine, CA 92697 \\ and NBER \\ dneumark@uci.edu \\ Matthew Thompson \\ Charles Rivers Associates \\ 1545 Raymond Diehl Road \\ Leslie Koyle \\ Charles Rivers Associates \\ 170 S. Main St. \\ Suite 1050 \\ Salt Lake City, UT 84101 \\ LKoyle@crai.com \\ Clayton Reck \\ Charles Rivers Associates \\ 1545 Raymond Diehl Road \\ Suite 260 \\ Suite 260 \\ Tallahassee, FL 32308 \\ Tallahassee, FL 32308 \\ creck@crai.com \\ mthompson@crai.com \\ Francesco Brindisi \\ New York City \\ Office of Management and Budget \\ 75 Park Place \\ New York, NY 10007 \\ fb2012@columbia.edu
}




\section{Introduction}

With the advent of the living wage movement in the early 1990s, labor economists and other policy analysts have been asked to estimate the future effects of imposing a local wage mandate in a city. Lacking an historical record, studies for the cities that were early implementers of living wage laws principally relied on ex-ante simulations using some existing data and survey evidence, coupled with assumptions about the effects of the mandates (e.g., Pollin and Luce, 1998). As more local governments adopted living wage laws, "before-and-after" (longitudinal) evidence became available (e.g., Neumark and Adams, 2003a), although the experience of other cities may not capture specific features of a given city's economic landscape or specifics of the proposed law.

In 2010, a proposal (Intro. 251) was introduced to significantly expand New York City's existing very narrow contractor-only living wage law to a broad "business assistance" living wage law intended to cover firms and real property receiving financial assistance from the City for economic development. The law would have covered employees, contractors, sub-contractors hired by the direct recipients of financial assistance, and tenants and sub-tenants, establishing a wage floor of $\$ 10$ per hour, or $\$ 11.50$ if health insurance was not provided. ${ }^{1}$

The New York City Economic Development Corporation (NYCEDC) commissioned a comprehensive study to estimate the effects that Intro. 251 would have had on labor and real estate markets (Charles Rivers Associates, 2011). The estimates are derived from ex-ante simulations specific to New York City, but the parameters used are informed by new longitudinal estimates for other cities. Moreover, the research uses extensive historical data on recipients of financial assistance, employer-level data from the Quarterly Census of Employment and Wages, as well as other data sources such as the American Community Survey.

Living wages have been and remain a contentious and politically charged topic, and the reception

\footnotetext{
${ }^{1}$ See http://legistar.council.nyc.gov/LegislationDetail.aspx?ID=664291\&GUID=A83A5A5B-9589-4589-AAD75B2C6884610F\&Options $=\mathrm{ID} \mid$ Text $\mid \&$ Search $=251$ (viewed November 2, 2011).
} 
of this study was no exception. ${ }^{2}$ The goal of this paper is not to argue about the effects of proposed legislation that, at time of this writing, has been revised and is still being considered. From a research perspective, this would be of little relevance, and the interested reader can consult the full study. Rather, the goal of this paper is to present to researchers and practitioners the comprehensive methods and data sources that are relevant and applicable to the evaluation of living wage policies and, more generally, the effects of public policy on local labor markets. We describe the results of our analysis along the way, to illustrate and explain our methods, while recognizing that other researchers, even following our approach, might do things differently and reach different answers. Regardless, we believe the methods and data we used provide a template for more thorough and compelling predictions of the effects of living wage mandates, and of related policies for which the data and methods are appropriate.

\section{Issues Highlighted in Prior Research}

To help lay the groundwork for our study, this section of the paper discusses issues raised in past research on living wages that bear on the methods used in our evaluation. ${ }^{3}$ In cases where the details were discussed in earlier work, they are touched on only briefly here. For comprehensive reviews of the living wage literature, see Adams and Neumark (2004a, 2004b), Holzer (2008), Pollin et al. (2008), and Charles Rivers Associates (2011).

\section{Ex Ante Studies}

Ex ante studies simulate the effects of wage mandates in a specific city prior to implementation; examples are provided in Tolley et al. (1999), Sander and Williams (2005), and Pollin et al. (2008). These studies have two key inputs: data describing the labor market in the city; and assumptions about the behavioral responses of firms and workers to the proposed living wage. By their nature, ex ante studies have to rely on simulations that are less compelling than policy evaluations based on treatment and comparison groups, although it is best to use as much actual evidence as possible to inform assumptions

\footnotetext{
${ }^{2}$ For example, see http://nelp.3cdn.net/67dcccd3fc93450105_14m6ibn7g.pdf (viewed December 13, 2011).

${ }^{3}$ This discussion is perhaps particularly useful because advocates for the New York living wage proposal dismissed our study out of hand (before it was done) as using flawed methods. See, e.g., http://www.fiscalpolicy.org/FPINELP_BackgroundLivingWageStudy.pdf (viewed March 19, 2011).
} 
about behavioral responses.

The key assumption is how the wage mandate will affect employment. The most prevalent ex ante studies, by Pollin and his co-authors (e.g., Pollin et al., 2008), assume that living wages do not reduce employment. From this it follows that living wages do not pose a tradeoff between wage increases for some workers and adverse employment effects for others, and accordingly these studies always conclude that living wage laws must on net help low-wage workers and low-income families. Illustrating the impact of this assumption on the findings, Tolley et al. (1999) assume disemployment effects and arrive at a much more negative assessment of a proposed living wage law in Chicago.

The rationale for the assumption of no disemployment effects in many ex ante studies is often speculative. Examples include: "New Orleans firms should be able to absorb most, if not all, of the proposed minimum wage ordinance" (Pollin et al., p. 68); and "If the high-end hotels in Santa Fe are competing for convention business, the decisive factor is not likely to be a price difference of 3-5 percent ...” (p. 90). Reference is sometimes made to research, usually on minimum wages (Pollin et al., 2008). Without going into a discussion of the evidence (see, e.g., Neumark and Wascher, 2008, for an extensive review), we would argue that while there is certainly some disagreement on the disemployment effects of minimum wages, concluding that they are nil requires a selective reading of the literature (Charles Rivers Associates, 2011).

\section{Longitudinal Studies}

After the passage of some time following the first living wage laws, Neumark and Adams (2003a, 2003b) estimated the effects on workers and families based on longitudinal comparisons between cities where the mandates were and were not introduced. The Neumark and Adams studies covered the inception of living wage laws in mid-1990s through 2002, using Current Population Survey (CPS) data from the monthly Outgoing Rotation Group (MORG) files, which capture individual wages and employment, and the March Annual Social and Economic Supplement (ASEC) files, which capture family income and participation in government programs. The analysis was done at the level of Metropolitan Statistical Areas (MSAs) or Primary Metropolitan Statistical Areas (PMSAs), based on where CPS respondents reside. (The CPS does not tell us where people work.) MSAs/PMSAs include 
areas surrounding the major cities whose living wage laws are studied, but MSA residents who live in suburbs tend to work in the central city, where jobs are concentrated (Cervero, 2002).

The studies estimate the effects of living wage laws on wages and employment at the low end of the wage or skill distribution (the bottom decile in each city-month cell), and on family income relative to needs. The regression models capture the magnitude of the living wage relative to the minimum wage, and include controls for skill as well as state and year dummy variables and differential trends for cities adopting living wage laws. The effects of living wages are identified from differential changes in outcomes in cities that implemented or raised a living wage relative to cities that did not - a difference-indifferences (DD) research design. Neumark and Adams also distinguished between contractor-only and broader business assistance living wage laws, and it is only the latter that turn out to matter.

Rather than just making assumptions, the New York City study uses the same methods and data to obtain updated estimates of behavioral responses to living wage mandates. Because we maintain that these kinds of longitudinal methods should be used for living wage studies, we now turn to consideration of some criticisms of these methods and the data on which they rely.

Fairris and Reich (2005, p. 10) dismiss the approach out of hand, claiming that estimates in Adams and Neumark (2005a) indicate that $91 \%$ of affected workers would lose their jobs, implying employment elasticities that are huge and simply implausible. This claim, however, is simply incorrect. Adams and Neumark consider a 35\% business assistance living wage increase. Given their estimated employment elasticity for those in the bottom decile of the skill distribution (the affected workers) of -0.076 , and that the employment rate in this group is $44 \%$, the employment effect implied by the increase they consider is $-6 \%$, an estimate that cannot be used to dismiss the methods out of hand. ${ }^{4}$

Second, some criticisms have taken issue with the evidence that business assistance living wage laws can matter more than contractor-only laws, claiming that hardly any workers have actually been

\footnotetext{
${ }^{4}$ Fairris and Reich erroneously apply the overall estimated labor demand elasticity implied by the estimates, which is -2.6 , to the percentage increase in the living wage $(-2.6 \cdot 0.35=-0.91)$. But the -2.6 elasticity is the percentage change in employment for a $1 \%$ increase in the overall wage paid to affected workers. Since the elasticity of wages with respect to the living wage is small (0.067), the correct estimate calculated this way has to multiply -2.6 by 0.067 , yielding a much smaller number.
} 
affected by the business assistance provisions of living wage laws (Pollin et al., 2008, pp. 242-6). This issue is relevant to the New York living wage study because the New York living wage proposal would cover business assistance recipients. Based on the earlier evidence in Adams and Neumark (2005b), there was reason to believe many workers were affected by business assistance coverage. There was and remains uncertainty over how many workers are covered by business assistance living wage laws, but the evidence does not support the claim that hardly any workers are affected.

Fairris et al. (2005) suggest that the number of workers employed by business assistance recipients whose wages were affected by the Los Angeles living wage law as of their 2001-2003 survey was only around 1,100 (their Tables 2.1 and 2.5). However, because the survey covers contractors only, it is not representative of assistance recipients. ${ }^{5}$ Moreover, in 2003 Los Angeles expanded its living wage policy to apply to employees of real estate developers that receive public subsidies (and their subcontractors), although not their tenants. Finally, Luce's (2004) book on the implementation of living wage laws concludes that coverage was extensive:

"In early 1998, coalition members got word of city negotiations over a large redevelopment project in Hollywood ... with major developer TrizecHahn ... In the end, TrizecHahn agreed not only to pay living wages and benefits to its workers but also agreed to require retailers leasing space in the development to pay living wages and give first priority in hiring to Hollywood residents. In addition, the living wage coalition won an agreement that required seven hundred to eight hundred of the staff positions at the new development to be unionized. The coalition went on to win similar agreements for other major developments in the city" (Luce, 2004, p. 122, italics added).

This quote is directly at odds with Pollin et al.'s claim (in a book of which Luce is a co-author) that "the findings that city administrations have applied the living wage business-assistance clauses to few, if any, firms, is consistent with Luce's (2004) extensive study on the successes and pitfalls of implementing living wage ordinances" (2008, p. 246).

Moreover, in a recent living wage study Lester and Jacobs (2010) explicitly try to identify a subset of cities that were "effectively implementing business assistance living wage laws" (p. 1), and

\footnotetext{
${ }^{5}$ They write, "The City of Los Angeles' enforcement database was used to identify contracts with low-wage workers. The lists of firms were stratified by industry and occupational groupings before a random sample of employers was taken" (p. 12).
} 
include three cities - Los Angeles, Minneapolis, and Oakland (their Table C) - for which Pollin et al. (2008) claimed hardly any workers were affected. Lester and Jacobs concur that we should expect larger effects from business assistance provisions of living wage laws: “[B]usiness assistance living wage laws are the type of economic development wage standard likely to have the most widespread effect on employment" (p. 3).

Pollin et al. (2008) (echoing Brenner et al., 2002) also try to argue that the Neumark and Adams estimates of the effects of business assistance living wage laws are flawed because they define "potentially covered workers as all private sector workers (usually about 90-95 percent of the workforce)" (p. 240). This is a mischaracterization. Neumark and Adams (2003a) tried to substantiate their results indicating that business assistance living wages increased wages of low-wage workers by attempting to distinguish workers who could not be covered from those who could potentially be covered. For contractor-only laws, the potentially covered workers include those in industries that might have contracts (based on the city's law), whereas for business assistance laws, an upper bound estimate would include the entire private sector - upwards of $90 \%$ of the workforce. Neumark and Adams explicitly state that they "chose the broadest definitions of potential coverage, so as not to exclude those that are potentially affected. At best, we identify those workers who could in principle be covered; actual coverage rates should be much lower than those we report.” (p. 509). Pollin et al. report results reclassifying workers as covered by living wage laws only if they work in service industries likely to be covered by contractor provisions. They then report as an independent finding that the Neumark and Adams results were reversed, with positive wage effects for the uncovered, and argue that "this wage growth cannot be convincingly linked to living wage laws because it is the uncovered workers, rather than the potentially covered workers, who experienced the wage growth" (p. 248). The point is irrelevant, of course: if the classifications of workers as potentially covered by business assistance versus uncovered are flipped, the results must also flip.

A third line of criticism is that the CPS data - which we also use in this study - do not deliver 
sample sizes sufficiently large to detect effects of living wage laws (Brenner et al., 2002; Pollin et al., 2008). But the calculation used to make this argument is in error. ${ }^{6}$ Moreover, the bottom line is that a standard research design for estimating policy effects produces estimates of non-negligible effects that, insofar as theory makes predictions, are consistent with expectations. It is hard to reconcile this evidence with claims that the CPS data could not possibly detect effects of living wages; indeed such arguments are usually made to counter failure to find a significant effect.

Of course one can ask whether there is a better alternative data set. Lester and Jacobs' (2010) recent study uses the National Establishment Time Series (NETS), a longitudinal data set on business establishments in the United States that has the advantage of identifying the cities in which business establishments are located. However, the NETS has information only on total employment counts, not on employment of workers in different skill groups or their wages. As a result, Lester and Jacobs can only test for aggregate employment effects - either for the private sector as a whole, or specific industries that might be more affected by business assistance living wage laws. They cannot estimate wage or employment effects on the least skilled, nor can they say anything about how living wages affect families; hence the NETS data cannot address the central policy question of whether living wage mandates ultimately help or hurt those whom they affect.

A final criticism is that the econometric methods are incorrect. Neumark and Adams focus attention on models estimated for the workers in the bottom decile of the wage distribution. Brenner et al. (2002) argued that this approach leads to spurious evidence of living wage effects, and that a quantile regression approach should be used to avoid this bias. They then estimated a quantile regression for the 10th percentile, with a striking difference in results. Whereas the initial Neumark and Adams estimate of the wage effect below the 10th percentile (which they replicate) was 6.95 (and significant) - implying an

\footnotetext{
${ }^{6}$ Brenner et al. assumed that Neumark and Adams required 25 (or 30) covered workers in their sample from Los Angeles-Long Beach to obtain reliable estimates, and based on the number of sampled workers and a coverage estimate, suggested that the odds of getting 25 workers was 1 in 500,000 (falling to 1 in 244,000,000 for 30 workers). The Los Angeles living wage law took effect in April 1997; hence, if the CPS samples 5,000 wage earners per year (as Brenner et al. say), the relevant sample size would be about 18,750 (5,000 multiplied by the 3$3 / 4$ years that the living wage law was in effect in the original sample in Neumark and Adams, 2003a). In this case, based on their coverage estimate, the expected number of covered workers in the sample would be 31 (1 more than the number that they argue Neumark and Adams would meet or exceed with a probability of only 1 in 244,000,000).
} 
elasticity of wages in this range with respect to living wages of 0.7 - the quantile regression estimate was only one-tenth as large, at 0.74 (and insignificant).

This is a misuse of quantile regression, however - one which should not replicate the positive wage effects, and would not detect a true positive wage effect. Neumark and Adams' regression looks at the wage distribution without conditioning on skill, picks out those below the 10th percentile in each citymonth cell, and then estimates the effects of living wages on wages at that point - asking whether living wage laws increase the wages of the lowest wage workers (those below the 10th percentile). In contrast, a quantile regression conditional on skill asks whether living wages increase the wages of those at the 10th percentile relative to wages of workers with similar characteristics, whether these workers earn high or low wages. But because living wage laws are simply floors on absolute wages, there is no reason to expect a general shift in relative wages within skill groups.

This discussion indicates that the earlier longitudinal studies of the effects of living wages are not flawed for reasons related to either data or methods, and are appropriate for assessing the historical evidence to inform the prospective evaluation of a living wage law.

\section{Empirical Evidence on Living Wage Mandates in Other Cities}

Evaluating the likely effects of New York's living wage laws required elements of an ex ante analysis that accounted for the uniqueness of the city and the proposed legislation, and answered specific questions regarding the effects of the proposed living wage law on programs - in some cases administered and financed by the city - that provide income or other support to low-income families. At the same time, evidence on the effects of living wages in other cities provides the best information on the actual effects of laws that have been implemented. Thus, we conducted an updated longitudinal analysis of living wages laws in U.S. cities to estimate the behavioral responses, and coupled this with rich, new data sources to try to capture as accurately as possible the specific features of New York City's labor market. In this section we describe the longitudinal analysis of other cities, and in the next section we describe the simulations for New York City.

\section{CPS Data on Labor Markets}

CPS data were used to extend earlier longitudinal analyses through 2008 or 2009, depending on 
data availability (the period covered by the ASEC files extended through 2008, versus 2009 for the MORG files). In the CPS data, geographic information is reported by place of residence according to a geographical classification system of "statistical areas" based on population density and commuting patterns. Before 2005, the system was based on four-digit Federal Information Processing Standard (FIPS) codes for the MSA, PMSA, or Consolidated Metropolitan Statistical Area (CMSA). In 2005, it changed to one based on Core-Based Statistical Areas (CBSA), labeled with five-digit FIPS codes. This change in geographic classifications poses problems, and is therefore discussed in some detail.

The pre-2005 MSA/PMSA/CMSA definitions grouped counties (or cities and towns in New England) based around one or more "central cities" that can cross state lines. Geographicallyinterconnected PMSAs are combined to form CMSAs, of which there are 18 in the United States. The post-2005 CBSA system is based on core urban areas instead of central cities. CBSAs are classified as either Metropolitan Areas or Micropolitan Areas, based on size requirements. Larger Metropolitan Areas are subdivided into Metropolitan Divisions, which are comparable to the subdivision of CMSAs into PMSAs in the pre-2005 definitions. One or more CBSAs may be grouped together to form a Consolidated Statistical Area (CSA). ${ }^{7}$

The Census Bureau provides a crosswalk mapping post-2005 CBSAs to their pre-2005 MSA/PMSA counterparts. ${ }^{8}$ The crosswalk contains 935 unique CBSAs (both Micropolitan Areas and Metropolitan Areas), but the 2005-2009 CPS data reports only 275 unique CBSAs, in large part because the CPS data does not report Micropolitan Area CBSAs. Of the 275 unique CBSA FIPS codes, 245 CBSAs could be mapped directly to an MSA or CMSA using the crosswalk provided. Another 16 CBSAs were manually mapped using the New England Cities and Towns Area (NECTA) definitions based on names. ${ }^{9}$ The last step in applying the crosswalk consists of consolidating PMSAs in the pre-

\footnotetext{
${ }^{7}$ For additional details, see http://www.census.gov/population/www/metroareas/mastand.html and http://www.census.gov/population/www/metroareas/metroarea.html (viewed October 5, 2010).

${ }^{8}$ The 2004 MORG file contains some CBSA codes and some MSA codes, suggesting that the change to CBSA occurred mid-year 2004 in the MORG file, while the ASEC definition change occurred distinctly between the 2004 and 2005 year files. The crosswalk was thus applied to the 2004-2009 MORG files, and the 2005-2009 ASEC files. ${ }^{9}$ After this matching, 14 of the 275 CBSA codes that remained do not match to any MSA or PMSA. These are generally smaller cities, such as Coeur D'Alene, ID and Bend, OR. However, these unmatched CBSAs are not
} 
2005 period into CMSAs, because the post-2005 CBSAs in the CPS data do not include Metropolitan Division distinctions. All PMSAs belonging to the 18 CMSAs in the United States were therefore rolled up into their appropriate CMSAs pre- and post-2005 in order to have consistent geographic areas across time.

These steps resulted in 215 unique MSA/CMSA areas. Geographic identifiers are suppressed (for confidentiality reasons) for 35 of these - some before and some after the change in geographic classification. Again, though, this is not pertinent to our analysis, because this suppression occurs only for smaller cities that get dropped because of too few observations. Thus, we have 180 MSAs or CMSAs defined on a consistent basis over the years we study.

To assess the accuracy of geographical linkages over time, we chose five MSAs/CMSAs for which the conversion was complicated and five that were simple, and computed the shares black, Hispanic, and with low educational attainment (high school degree or equivalent), and weighted population estimates, over time in both the ASEC and MORG data. We wanted to check for breaks at the time of the switch in geographic classification, which could point to inconsistent geographic definitions over time. There was no indication of unusual changes surrounding the switch in geographic definitions in 2005, for either the simple or the complicated CMSA aggregations. A more problematic issue, discussed below, is the accurate measurement of the living wage in these MSAs/CMSAs, in cases where living wages are in place in only some cities in the MSA/CMSA, or differ across them.

The empirical analysis is done with individual-level data. However, the analysis requires the estimation of deciles and other percentiles of the wage or predicted wage distribution for MSAs/CMSAs, by month or year. To ensure a reasonable level of accuracy in doing this, we required that an MSA/CMSA had at least 50 observations of individuals age 16-70 in all months of the sample period 1996-2009. To have comparable analysis samples of the MORG and the ASEC data files, we required that this be met for both data files. This requirement was met by 39 of the unique MSAs/CMSAs after the

relevant for our analysis, because we restrict the data to urban areas with a minimum number of observations (described below), and none of the unmatched CBSAs meet the criterion for the minimum number of observations. 
geographic matching and roll-ups. ${ }^{10}$

\section{Data on Living Wages}

Cities, rather than metropolitan areas, are the political units that adopt most living wage laws.

We characterize the living wage laws prevailing in a metropolitan area based on the living wages passed by the major cities in the MSA. Given the change in geographic coding, it is not entirely straightforward to define a list of cities on which to focus for the entire analysis period. Prior to the change, the classification of larger cities was based on the definition of "central cities" (Frey et al., 2004), but with the switch to CBSAs larger cities were classified as "principal cities." We needed to choose a set of cities within the 39 MSAs/CMSAs for which to code living wage laws in detail. We chose all central or principal cities subject to two criteria: a population of at least 250,000 residents according to 2000 Decennial Census data; ${ }^{11}$ and if no city in the metropolitan area had at least 250,000 residents, the largest city in the metropolitan area. These criteria led to 52 cities within the 39 MSAs/CMSAs, reported in Table 1.

For these cities, we needed historical information on living wage laws and other characteristics of the laws, such as whether they apply to recipients of financial assistance. We first reviewed city websites for evidence of a living wage law and to identify a contact for follow-up. For cities where we initially found no evidence of a living wage law, we attempted to contact the City Clerk, City Manager, City Attorney, or Procurement/Public Works/Economic Development Officer by telephone to confirm whether the city had a living wage law at any time since 1995. If we were unable to reach the city representative by telephone, we followed up with email correspondence. At times, the first point of contact within a city directed us to another contact, at which point we would repeat the process (call, followed by email). If the representative confirmed that the city never had a living wage law, we "closed" the research on the city. If the representative indicated that there was, or had been, a living wage law, we added the city to the list for further research.

\footnotetext{
${ }^{10}$ We used a more stringent criterion than in the earlier Adams and Neumark studies, since we wanted to focus on larger cities more likely to be comparable to New York City.

${ }^{11}$ See http://www.census.gov/popest/cities/ (viewed November 9, 2010).
} 
For the cities with evidence of a living wage law, we obtained as much possible information from 1995 through 2010 from the city website or directly through a city representative. Using the city website, we reviewed the current living wage law found in the city's municipal code or code of ordinances which, at times, contained a reference to the ordinance creating the code. ${ }^{12}$ The documents reviewed in the search typically generated information on the living wage history (e.g., council agendas/minutes, budget presentations, or living wage ordinance summaries), or reference forms containing the living wage rates (e.g., posters, memorandums, or living wage rate change bulletins), from which we gained additional detail. Once we established the broad picture, we used specific dates to track down the actual ordinances adopted and the living wage rates established during a given year. If necessary, we contacted city representatives by telephone or email to confirm findings or provide information that was not attainable from the city web pages. Using this information, we coded the wage levels for the 23 cities with living wages, for each year and month from January 1995 through December 2009. ${ }^{13}$ We also coded whether or not the living wage law applies to business assistance recipients. ${ }^{14}$

Results: Wage and Employment Effects

The first two columns of Table 2 repeat the basic estimates, published in Adams and Neumark (2005b), of the effects of living wages on wages of workers in the bottom decile of the wage distribution, and the bottom decile of the skill (predicted wage) distribution. The data cover all residents of MSAs and PMSAs identified in the CPS ORG data in the 1996-2002 period, in city-month cells with 25 or more observations. The key living wage variable in the model, for which estimates are reported in the table, is

\footnotetext{
${ }^{12}$ We also used the search bar provided on the city website to search for items containing "living wage," "living," "wage," "livable," "equal wage," and any ordinance information collected from the current code.

${ }^{13}$ Some cities passed laws that were never implemented, for instance because of a subsequent court decisions (see Adams and Neumark, 2005a). Only living wage laws that were actually implemented are included.

${ }^{14} \mathrm{We}$ collected extensive information on other characteristics of living wage laws, with the goal of estimating effects of living wage laws even more similar to New York City's proposal. However, as detailed in Charles Rivers Associates (2011), no city had the panoply of penalties and costs proposed for New York City, including putting the burden of monitoring costs on the developer or owner of a building, or repayment of subsidies for violations. More generally, it turned out to be fruitless to estimate the effects of other features of living wage laws that have parallels to the proposed law in New York City, because there simply are not that many cities with living wage laws, and once we look for specific features of the laws, there is at most a handful of them. As a consequence, the longitudinal analysis could not be used to learn about the experiences of other cities with living wages similar to that proposed for New York City - highlighting why ex ante simulations that capture the unique features of a city's law can be important.
} 
the log of the maximum of the living wage or the minimum wage prevailing in the city, lagged 12 months. The maximum of the two is used to capture the effective wage floor, and the 12-month lag is used based on evidence that the effects of living wages do not occur instantly but emerge over about one year. The regressions include controls for city, year, month, minimum wages, and other individual-level controls. The specification also includes differential linear time trends for cities passing or not passing living wage laws, or passing different types of laws. The first row reports the estimates from a single regression on the living wage variable, without distinguishing the type of living wage laws. In the second and third rows, instead, each column reports results from a specification that distinguishes between contractor-only and business assistance living wage laws (by interacting the living wage variable with dummy variables for these types of laws, constructed to be mutually exclusive).

The wage equation is a log-log specification, so the coefficients are elasticities. For example, the upper-left estimate means that a $100 \%$ increase in the living wage (e.g., from a $\$ 5$ minimum wage to a $\$ 10$ living wage) would increase wages in the bottom decile of the wage distribution by 0.04 log points, or approximately $4 \%$. The coefficients from the employment regressions measure the change in the share employed in response to a one-unit increase in the log living wage (or a $100 \%$ increase).

For the first specification, the estimates in columns (1) and (2) indicate that living wages lead to higher wages and lower employment; only the estimated employment effect is statistically significant. In the second specification, business assistance living wage laws have significant positive effects on wages, and significant negative effects on employment, whereas the effects of the narrower contractor-only laws are smaller and insignificant (and the wage effect is very close to zero). The magnitudes imply that a $100 \%$ business assistance living wage increase boosts wages in the bottom decile of the distribution by $6.7 \%$, and reduces employment in the bottom decile by $7.6 \%$.

The remainder of Table 2 shows the consequences of some changes to the sample necessitated by the aggregation of MSAs/PMSAs to MSAs/CMSAs, and of other changes to the data or specification. First, columns (3) and (4) report estimates using the exact same data and specifications, but restricting attention to the MSAs/PMSAs that are aggregated to MSAs/CMSAs in what follows. This entails very small reductions in the sample size, as only 12 very small MSAs/PMSAs that were included in the 
original analysis are dropped. For the wage analysis, 79 MSAs/PMSAs meet this criterion and other sample size restrictions. More MSAs/PMSAs meet the sample size restrictions for the analysis of employment, because the samples for these outcomes are larger. However, we report most results for the consistent set of MSAs/PMSAs. We also report key results for the largest possible samples of MSAs/PMSAs within these MSAs/CMSAs, on the argument that these give us the most reliable estimates for each outcome. The changes in the estimates shown in columns (3) and (4) are inconsequential.

Columns (5) and (6) incorporate some slight changes in the living wage data based on the new research on the history of living wage laws. Most of the estimates are essentially unchanged, with the exception of the employment effect for contractor-only living wage laws, which is now the same magnitude as for business assistance laws and statistically significant. Columns (7) and (8) report specifications in which less-restrictive linear trends - now, simply city-specific linear trends - are substituted for the differential linear time trends for cities passing or not passing living wage laws, or passing different types of laws. For business assistance living wage laws, which are our main focus, this change has little bearing on the estimates. Again, though, the results for contractor-only laws are more sensitive (and, consequently, so are the results for living wage overall). In particular, there is now no evidence of a statistically significant positive wage effect for living wages overall, or of significant (positive) wage effects or (negative) employment effects for contractor-only laws. Nonetheless, the conclusion is still that business assistance living wage laws lead to positive wage effects and negative employment effects, both of which are statistically significant. The estimates with city-specific trends become our "baseline" estimates for purposes of comparison going forward.

Table 3 explores the consequences of extending the data through 2009, which requires the aggregation to MSAs/CMSAs. Now the key variable in the model, for which estimates are reported in the table, is the log of the maximum of the minimum wage or the weighted living wage (weighted by population share of the MSAs or PMSAs in the MSA/CMSA), lagged 12 months. This weighted living wage variable is calculated by multiplying the living wage in an MSA/PMSA by the population share of that MSA/PMSA in the total MSA/CMSA population living in MSAs or PMSAs (based on 2000 Census data), and summing the weighted living wages across all MSA/PMSAs in the MSA/CMSA. 
As columns (3) and (4) show, once we aggregate and extend the data, the evidence changes relative to the baseline estimates (columns (1) and (2)). For wages, the estimated effects of the overall living wage and the two separate living wage variables are all positive but statistically insignificant, and the estimate for business assistance living wage laws - which was larger and statistically significant in the previous analyses - declines. For the employment effects, although all of the estimates are negative, none is large compared to the overall and business assistance living wage effects estimated earlier, and the estimate for business assistance living wages, which should have the highest coverage, is not significant.

Illustrating that the problem is the aggregation of MSAs and PMSAs to MSAs/CMSAs necessitated by the changes in the CPS data, in columns (5) and (6) we keep everything the same as in columns (1) and (2), and the only change we make is to do this aggregation. The estimates also change substantially relative to columns (1) and (2) and are not very different from those when we extend the data through 2009.

The aggregation to MSAs/CMSAs poses a severe empirical problem for a very simple reason: it is difficult to measure living wages at the MSA/CMSA level because of many instances in which MSAs or PMSAs within a MSA/CMSA adopt living wages at different times (and also at different levels, although the differences in timing are the more serious issue). Table 4 illustrates the problem, for the case of Boston. Boston passed a living wage in 1998, while the other MSAs and PMSAs in the CMSA did not. For the years in the sample period through 2002 (when the original analysis ended), somewhat under half the observations in the CMSA are outside of the Boston PMSA. In the original analysis through 2002, the Boston living wage was assigned only to the Boston PMSA. However, with the change in geographic classification, the other five MSAs/PMSAs were aggregated with the Boston PMSA, resulting in the living wage being assigned to all six of them beginning in July 1998, when the Boston living wage was implemented. Table 4 shows that in 1996 and 1997, when there was no living wage in Boston, there is no measurement problem. The living wage takes effect midway through 1998, so the percentage of observations with the wrong living wage (and the average magnitude of the error) is fairly small in that year. In subsequent years, though, the error rate and magnitude of the error becomes considerably larger. There is a similar aggregation problem for other cities for which MSAs/CMSAs include 
MSAs/PMSAs with different living wages. There are only 20 MSAs/CMSAs that do not suffer from either problem, and only five of these have living wage laws; hence we could not reliably estimate living wage effects for the full sample using this subset of observations.

As a consequence of this aggregation problem, the best alternative is likely to revert to the specification at the MSA/PMSA level, using as long a sample period as possible. For the analysis of wages and employment, this implies extending the sample period through 2004, which unfortunately does not provide as much "updating" as we would like. Results are reported in the final two columns of Table 3. There are some changes relative to the baseline estimates in columns (1)-(2). For the living wage variable overall, and the business assistance living wage variable, the estimated wage effects are smaller, and the wage effect for business assistance living wage laws is no longer statistically significant, although the estimated coefficient still implies a sizable effect: a 100\% living wage increase boosts wages in the bottom decile of the wage distribution by 5.1\%. For employment effects, in contrast, the evidence is somewhat stronger. There is still evidence of a statistically significant negative effect of business assistance living wage laws on employment of less-skilled individuals and of living wage laws overall. But now the estimate is similar, and statistically significant, for contractor-only living wages as well. ${ }^{15}$

We also estimated these specifications for different ranges of the wage and skill distribution, which is of interest because a living wage can generate demand shifts toward higher-skilled workers, increasing their wages and employment (e.g., Fairris and Bujanda, 2008). And as Adams and Neumark (2005b) showed, many poor families have workers who earn relatively low wages or have relatively low skills but are not necessarily in the bottom $10^{\text {th }}$ of the distribution. Thus, policies that end up helping workers who are in a higher part of the wage distribution can reduce poverty. ${ }^{16}$ We found little evidence of effects higher up in the wage or skill distribution. The wage effects were small and centered on zero,

\footnotetext{
${ }^{15}$ If there is some disemployment, then presumably some of the lowest-wage workers lose their jobs (or do not get hired), in which case, by construction, wages in the lowest decile must increase. Thus, a precise estimate of a wage effect of zero would be puzzling given the evidence of disemployment effects. However, we instead find a relatively imprecise estimate of a sizable wage effect.

${ }^{16}$ This same point helps explain why it is in no way contradictory to find that living wages reduce poverty but minimum wages do not (Wu et al., 2006; Neumark et al., 2005). The gains and losses from living wages may be of different magnitudes, affect different workers, and fall at different points in the distribution of family income than do the gains and losses from minimum wages.
} 
and not statistically significant. The estimated employment effects were also small and statistically insignificant, although more uniformly negative. These results suggest that effects of living wages on the distribution of family incomes stem mainly from the effects of living wages on the lowest-wage and lowest-skilled workers. As a result, in the simulations for New York City below, we focus only on effects on the lowest-wage workers.

\section{Results: Effects on Low-Income Families}

We next report estimates of similar regression models, but for family income. These estimates tell us how the various and possibly complicated wage and employment (and hours) effects on individuals ultimately affect families. Table 5 focuses on whether living wages reduce the probability that families are poor. These models are estimated for the full sample, not the lower decile of the wage or skill distribution (or other ranges). Column (1) repeats the estimates from Adams and Neumark (2005b). The estimates are negative for living wages generally and for business assistance living wages (although the point estimate is larger for contractor-only living wages). To interpret the estimates, the -0.024 estimate for business assistance living wage laws, for example, implies that a $100 \%$ increase in this type of living wage reduces the poverty rate by 2.4 percentage points. Columns (2) and (3) report the results for the restricted sample (79 cities), and then with city-specific trends. The results are now more consistent with business assistance living wage laws being the only types of living wage laws that reduce poverty.

We next return to the issue of aggregation of urban areas into MSAs/CMSAs, which is necessary to update the results fully. Doing the aggregation without changing the sample period (column (4)) leads to estimates that might be regarded as implausibly large. In columns (5)-(6), we show the aggregated estimates through 2009, and then the disaggregated estimates (which we think are most reliable) through $2003,{ }^{17}$ the last year for which the disaggregated data are available. The basic qualitative conclusionthat business assistance living wage laws reduce urban poverty - is robust across all of these estimates. However, the estimates through 2003, without aggregating, no longer show a statistically significant

\footnotetext{
${ }^{17}$ This analysis extends through 2003 (and not 2004, the last year before the geographic classification changed), because the ASEC files cover the previous year.
} 
effect of business assistance living wage laws in reducing poverty. And for reasons already explained we have the most confidence in these estimates. ${ }^{18}$

Given that many income-support programs require low family income to qualify or tie benefits to income, we might expect that the beneficial effects of living wages be more limited than the increase in earnings, because rising earnings reduce eligibility for benefits or the amounts for which workers are eligible from social programs such as Medicaid, S-CHIP, Food Stamps, housing assistance, and the Earned Income Tax Credit decline. The evidence in Table 6 is consistent with this prediction. Higher business assistance living wages are associated with significantly lower probabilities that families receive welfare, live in public housing, or receive energy assistance. The point estimates also suggest they reduce payments from welfare or food stamps, but these estimates are small and imprecise.

One implication is that families that see earnings rise because of a living wage law would also receive fewer government benefits. This might be of interest to local policymakers to the extent that these benefits come from the federal (or state) government and would therefore imply less money coming into a city. As a prime example, the federal Earned Income Tax Credit (EITC) has grown into the largest program for providing income support to lower-income families (Blank, 2002). As a consequence, when a worker's earnings rise, the inflow of federal dollars via the EITC can decline substantially. On the other hand, the expenses for benefits paid by the local government would fall. As a consequence, our ex ante simulation goes into more detail on how the proposed living wage law would affect local, state, and federal expenditures on income-support and other programs in New York City.

\section{Ex Ante Simulations of the Effects of the Living Wage in New York City}

We establish a baseline for our simulation by providing a detailed description of workers and families that could be affected by the proposed living wage law, and then project how they would be affected. We use multiple inputs, including data on New York City workers, families, and business establishments, estimates of effects of living wage laws that are broadly applicable to New York City, and

\footnotetext{
${ }^{18}$ We re-estimated the model in column (6) using the larger sample of 91 MSAs/PMSAs that does not restrict attention to the subsample for which we do the wage analysis. The results were very similar.
} 
information on income-support and other programs available to New York City residents and how eligibility and benefit levels are determined. The estimates of behavioral responses to living wage laws, where appropriate, come from the previous section of the paper. The other inputs - including the data used for New York City - are described next.

Data

The American Community Survey (ACS) contains detailed information on where people live and work, and can therefore be used to construct a detailed portrait of the New York City workforce and the population affected by the proposed living wage law. We also use the ACS to identify workers based on their wage levels, their industry and borough of employment, their place of residence, and the characteristics of other members of their families. We use the three-year ACS sample covering 20062008, which collects yearly data re-weighted to yield average values over the sampling period.

To identify workers directly affected by the proposed living wage, we had to identify covered work sites and obtain information about workers and earnings at these sites. Typically, tax expenditures for economic development in New York City are tied to construction or renovation of real estate. Various programs are in place that exempt the change in properties' assessed values for a number of years (New York City Department of Finance, 2011; New York City Economic Development Corporation, 2012). The New York City Department of Finance provided us with longitudinal data on commercial and residential properties receiving tax exemptions for Fiscal Years (FY) 1984-2011. ${ }^{19}$ The living wage proposal included a minimum financial assistance threshold of $\$ 100,000$ for mandating living wages. However, it was not specified how to calculate the threshold (net present value, yearly assistance, etc.); the analysis was conducted based on buildings that received real property tax exemptions of $\$ 100,000$ or more in at least one fiscal year. ${ }^{20}$ The proposal also required that, once the threshold was met, the

\footnotetext{
${ }^{19}$ New York City fiscal years run from July 1 of a calendar year to June 30 of the following year, and are referenced by the calendar year on June 30. Based on the proposed legislation, the types of exemptions considered were: Industrial and Commercial Incentive Program (ICIP), 421-a, NYC Industrial Development Agency, and NYC Economic Development Corporation.

${ }^{20}$ There are relatively few investments entering the real estate exemption programs post FY 2008 because of the economic downturn. Furthermore, employment concentrates in commercial properties and the largest program for commercial properties (ICIP) was reformed and only applications submitted by the end of FY 2008 could qualify for
} 
mandates would apply for the life of the financial assistance or 30 years, whichever was longer.

The information on properties receiving tax exemptions was matched to business establishments in the Quarterly Census of Employment and Wages (QCEW) data for 2006-2008 - confidential data provided to NYCEDC for the analysis. ${ }^{21}$ These data are used to estimate the share of workers potentially affected by the living wage law and the increases in wages that would be experienced by affected workers. The QCEW has information on average quarterly earnings and number of jobs, by establishment, and on the address of each establishment, which was geocoded to real properties; ${ }^{22}$ we matched to sites that ever received assistance through FY 2011, to provide the most representative snapshot of what kinds of businesses locate in properties receiving financial assistance. This information is used to estimate the share of workers at covered sites, by borough and by industry.

We want to estimate how many of the workers at sites that received real property tax assistance at some point in the period FY 1984-FY 2011 ("covered sites") would be affected by the proposed living wage law, and by how much. However, because we have no information about the distribution of wages within a QCEW establishment, we estimate the wage distribution and hence the share of workers paid less than $\$ 10$ per hour. ${ }^{23}$ We first estimate the percentiles of the wage distribution by industry and borough of employment using the ACS. We cannot just assume that the ACS wage distribution holds equally at all establishments in the industry and borough, because wage levels may vary across employers. We

it. ICIP was replaced by the Industrial and Commercial Abatement Program (ICAP) but our data do not contain information on abatements.

${ }^{21}$ There are confidentiality restrictions on the QCEW data. The analysis reported here was based on aggregated information satisfying the following two restrictions: each sample includes no less than three employers; and each employer accounts for less than $80 \%$ of the total. In the case of single-establishment employers, the QCEW data always refer to that establishment. For multi-establishment firms, the data reported by the employer are generally broken out by establishment. We always use the data at the establishment level except when we know the firm has multiple establishments but the data are not reported by establishment, in which case we treat the firm as an establishment and assign employment to the address reported in the QCEW.

${ }^{22}$ Because the geocoding is time intensive, we only geocoded data for one quarter from each of the three years covered by the ACS data, and then matched the data for this quarter to the QCEW data for other quarters and averaged employment and earnings over the calendar year. We used data from the third quarter because the data indicated a disproportionate share of births in the first quarter of the year and a disproportionate share of deaths in the fourth quarter.

${ }^{23}$ The $\$ 10$ per hour floor is wage rate in the proposed living wage legislation when health benefits are provided by the employer. We use this rate in the simulations to be consistent with the estimates using the CPS data. If we were to assume that health benefits were not provided, the hourly rate associated with the proposed living wage law would increase to $\$ 11.50$ per hour, which, on its own, would imply somewhat larger effects. 
therefore use the QCEW, for each industry and borough, to estimate the wage level for covered establishments. This, in turn, requires an estimate of average hours worked at establishments. We use the ACS data to estimate average hours by industry and borough of employment and apply this to the QCEW data, by industry and borough, to estimate average wages. Finally, we compute the percentage difference between the average ACS hourly wage and the average QCEW wage in the industry and borough, and then adjust the percentiles of the ACS wage distribution by this amount to arrive at an estimated wage distribution for employees at covered establishments. ${ }^{24}$ We can then calculate the wage increases needed to bring wages up to $\$ 10$, and the implied average percentage wage increase for affected workers and for all workers. This calculation approximates the change in wages that would actually occur in New York City if those earning less than $\$ 10$ at covered sites were brought to that level.

Finally, we incorporated information on a wide range of income-support and other assistance programs that are provided through federal, state, and city resources to New York City residents. Many of these programs have eligibility requirements or determinants of benefit levels based on household characteristics that are not reported in the ACS data, and others provide benefits that cannot directly be measured in dollar terms (e.g., Home Energy Assistance Program and NYC Housing Authority Resident Employment Services). Thus, we limited our analysis to three larger programs - SNAP (formerly food stamps), the EITC (federal, state, and New York City's), and Medicaid - for which eligibility and benefit levels can be determined from the ACS data. SNAP and EITC benefits can be measured in dollar terms, whereas the dollar benefits of Medicaid depend on the family's usage of medical services. We therefore measure the effect of the proposed living wage in terms of dollars for the SNAP and EITC programs and in terms of participation for the Medicaid program. Because the ACS data do not provide detailed information on assistance program participation or with which to predict participation well, we assume all families that are eligible to participate in a particular program based on simulated family earnings do

\footnotetext{
${ }^{24} \mathrm{We}$ do the adjustment proportionally to avoid getting negative adjusted wage percentiles. The proportional adjustment parallels the standard wage equation specifications in the labor economics literature in which log wages are regressed on industry, occupation, or - when available - establishment dummy variables (e.g., Groshen, 1991). We do this for all for-profit employers at covered sites.
} 
participate.

\section{Methods}

We begin with wages. The QCEW data provide estimates of the share of employment in each borough and industry at covered sites. For each borough ( $b$, based on place of work) and industry (i) we denote the share of workers earning less than $\$ 10$ per hour who are employed at sites that received assistance in that borough and industry as $C E_{b i}$, which is the number of workers earning less than $\$ 10$ per hour employed at sites receiving assistance in a borough and industry divided by the total number of workers earning less than $\$ 10$ per hour in the same borough and industry.

To simulate the effects of the living wage, we have to assign wage increases to some workers who earn less than $\$ 10$ per hour. In the ACS data, we can identify workers employed in any borough $b$ and industry $i$ who earn less than $\$ 10$ per hour. Using the estimates of $C E_{b i}$ from the QCEW data, we apply the living wage to the borough and industry using the following method. For all workers employed in borough $b$ and industry $i$, we take those who earn less than $\$ 10$ per hour and give them a wage of $\$ 10$ per hour with probability $C E_{b i}$, while leaving their wage unchanged with probability $\left(1-C E_{b i}\right)$. For those who are assigned the living wage rate, we assume no change in hours or weeks worked. For the purposes of calculating how the living wage would affect the wage distribution, this "random assignment" is better than just giving everyone the "expected" increase. Giving everyone the expected increase would lead to badly estimated distributional effects. This is particularly important when we examine whether a family is pushed above an income threshold, which can be very different depending on how the benefits are distributed.

Some individuals in the ACS data have wages below the minimum wage (either due to measurement error, non-compliance with local minimum wage laws, or inapplicability of the minimum wage). We assume most individuals who would be subject to the law have an hourly pay rate at or above the minimum wage, and therefore in the simulations restrict the population eligible for a wage increase to those who report a wage that is at or above the 2006 minimum wage that is applicable to New York City 
workers - $\$ 6.75$ per hour. ${ }^{25}$ We also exclude self-employed earners. These restrictions reduce measurement error from individuals reporting unusual hours, earnings, and weeks worked in the ACS.

The ACS data are reported at the individual level, but the individuals are representative individuals with specific weights based on the number of actual persons in New York City that they represent. In order to apply wage changes randomly to individuals working in New York City, we expand the ACS data by creating duplicate records for each individual based on their household weight. Using this expanded file, we randomly assign the living wage to individuals earning less than $\$ 10$ per hour by borough and industry based on the above method. The household weight was used so that we could aggregate individuals back to a complete household level (each person in the household receives the same household weight).

The QCEW data capture those who work in New York City without regard to where they live. However, the ACS data capture place of residence and place of work. Since we are primarily interested in the effects on residents of New York City, we report the wage and employment effects for New York City residents. Nonetheless, some of the effects of the living wage would fall on residents of other cities and states who work in New York City. Below, these "outflows" are reported separately from the results pertaining to New York City residents and are labeled "Outside New York City."

Given that our estimates from the CPS data indicate some probability of job loss, we also assign job loss to simulate the effects of the proposed living wage law. We tie our projected employment effects explicitly to the CPS evidence, although we do not do this for wages because the CPS results on wages were less precise, and for New York City the QCEW data provide us with good measures of the wage distribution at affected firms. This reflects the tradeoffs between relying on longitudinal studies of other cities versus ex ante simulations; with regard to wages, we have more specific information about likely effects on wages in New York City, and hence incorporate that information.

For most boroughs and industries, a $\$ 10$ per hour living wage rate is above the $10^{\text {th }}$ percentile of

\footnotetext{
${ }^{25}$ The applicable minimum wage is $\$ 6.75$ in 2006 and \$7.15 in 2007 and 2008. In an effort to reduce the number of individuals excluded due to timing or reporting issues, we use the 2006 level in all years.
} 
the wage distribution, implying that the estimated CPS employment effects would apply only to workers earning less than the living wage. However, we assume that our CPS employment elasticity to mandated wage increases above the minimum wage for the lower decile would approximately fall on the workers who, according to the QCEW data, would have their wages affected by the living wage, hence applying the earlier estimates for workers in each borough and industry that have wages below $\$ 10 .^{26}$

We calculate the predicted decline in employment among those workers earning below $\$ 10$ per hour, given the proposed living wage increase and the earlier estimates. This yields, overall for the city, a predicted probability of job loss, denoted $p$. For each industry and borough we have an estimate of the share of workers earning less than $\$ 10$ per hour working at covered sites $\left(C E_{b i}\right)$. We want to assign job loss with higher probability to those who are more likely to be working at a covered site, based on their industry and borough of employment. To do this, we construct the probability that a worker earning less than $\$ 10$ per hour working in borough $b$ and industry $i$ is at a covered site relative to the probability that any worker earning less than $\$ 10$ per hour working in the city is at a covered site $\left(C E_{\text {city }}\right)$. We then use a probability of job loss for a worker earning less than $\$ 10$ per hour in borough $b$ and industry $i$ of $p \times\left\{C E_{b i} / C E_{c i t y}\right\}$.

The simulations give us new wages for some workers and different employment statuses for others. Using these wage and employment changes for individuals, we simulate the effects of the living wage law on families by calculating how the distribution of family income changes, in particular relative to the poverty line and one-half the poverty line ("extreme poverty"), using the poverty thresholds for New York City from the New York City Center for Economic Opportunity (2011).

Finally, we simulate the effects on income-support and other programs. Program participation and benefit levels are estimated based on the current rules and award levels. The specific eligibility guidelines and charts showing benefit levels were obtained through state and federal government websites

\footnotetext{
${ }^{26}$ By applying the probability of job loss to more than those in the bottom decile, the resulting simulated job loss estimates may be slightly higher than those suggested by the CPS estimates for the lowest $10 \%$ of wage earners.
} 
providing program details. ${ }^{27}$ Medicaid and EITC eligibility and benefits are determined based on family income and number of family members. SNAP eligibility and benefits were also determined based on family size and income and applied the standard household and shelter deductions. Estimated EITC eligibility and benefit levels are based solely on family income, family size, and family structure (age of family members), and implicitly assume families pass the other eligibility requirements for which we have no data. We calculate family eligibility and benefit levels prior to assigning wage and employment effects, and then after assigning the simulated effects that we project would result from the living wage law, to determine how assistance would be impacted.

The living wage proposal we studied would apply to new recipients of financial assistance and to existing recipients in case of renewal or amendment of the original agreements. We do not know when or if current sites receiving financial assistance would, in the future, be new recipients as a result of assistance renewal, or when new developments will qualify for and receive assistance in the future. As a consequence, we know of no reliable way to, for example, isolate some sites that would be recipients of new financial assistance in the next year, the next two years, etc. Instead, we assume the effects apply to all covered workers. As a result, the results should be thought of as long-run effects. Given that most other cities also apply business assistance provisions of living wage laws to new projects only, and have been implemented at different times, it is likely that the estimates from the CPS data are intermediate between short-run or long-run effects.

\section{Living Wage Coverage}

Our calculations of the percent of employees who would be subject to the living wage law, and the simulations that follow from them, are based on sites that received real property tax assistance of $\$ 100,000$ or more in at least one year. This threshold (rather than any assistance) is more consistent with living wage laws in other locations, and hence the CPS estimates are more applicable to a definition of

\footnotetext{
${ }^{27}$ See http://www.health.state.ny.us/health_care/medicaid/ (viewed February 8, 2011); http://www.irs.gov/individuals/article/0,,id=96406,00.html (viewed April 5, 2011); http://otda.ny.gov/main/programs/tax-credits (viewed February 8, 2011); and http://www.fns.usda.gov/snap (viewed April 5, 2011).
} 
coverage based on this criterion. Based on workers employed at sites that received $\$ 100,000$ in assistance, the estimated percentage of workers earning less than $\$ 10$ per hour who would have been subject to the living wage laws ranges from $9.9 \%$ in Brooklyn to $31.3 \%$ in Staten Island, and is $12.9 \%$ across all boroughs. There is also considerable variation across industries, from $4 \%$ in construction to $24.4 \%$ in retail trade. The potential impact of the living wage legislation depends on the percentage of low-wage workers employed at sites receiving assistance and the number of low-wage workers in the industry.

\section{Wage and Employment Effects}

The dark bars in Figure 1 show the baseline wage distribution (up to \$13.50) for those living and working in New York City. The chart includes all those with positive wages, but in our simulation only those earning between $\$ 6.75$ and $\$ 10.00$ could have their wages changed by the living wage; restricting the simulation to those earning at least the minimum wage concentrates the effects on those employees who are most likely subject to the living wage requirement. The second set of bars (labeled "Implementation of Living Wage") shows the wage distribution after simulating the wage effects, with no employment effects. This bar is below each of the baseline bars less than $\$ 10$ and then spikes at $\$ 10$, with no changes above the proposed living wage, because those who are assigned wage changes have their wages increased to $\$ 10$. The last bar shows the distribution of individuals after simulating the employment effects as well, where those who become disemployed are assigned a wage of zero. In each instance the third bar is slightly below the second bar for wages of $\$ 10$ or less, and these reductions cumulatively add to the small mass in the $\$ 0$ wage column, reflecting job loss.

To provide some information on the variation in these effects across boroughs, and in an industry that would likely be strongly affected, Figure 2 reports results for retail by borough. The figure is limited to those who either received a wage increase (to $\$ 10$ ) or experienced a job loss. The largest impacts appear in Staten Island and the smallest impacts in Manhattan.

Table 7 provides more information on these wage and employment effects. It shows that the proposed living wage would impact a little more than $1.2 \%$ of the workforce and would have small impacts on wages $(0.1 \%$ increase $)$ and employment $(0.2 \%$ decrease $)$ overall. But these percentages are 
more than twice as high in the Bronx as in Manhattan, owing to differences in both industry composition and wage levels. The table also shows that the average overall wage increase is small ( $\$ 0.02)$, while the average increase for those who receive the living wage is substantial $(\$ 1.67)$. These effects vary in a similar way by borough. Finally, we see that some (approximately $8 \%$ ) of those receiving the benefit of the living wage mandate reside outside of New York City, suggesting that "leakage" to non-residents is not very large.

\section{Effects on Poverty and Family Income}

The solid bars in Figure 3 show the baseline distributions, by borough, of families by income-toneeds categories, and the dashed bars show the distributions after simulating the effects of the living wage. As shown in the figure, there is almost no observable change in the income distribution in terms of these thresholds. Thus, the simulated impacts of the living wage legislation suggest very small but mixed results on poverty. As shown in Table 8, overall the "extreme poor" would slightly increase by 0.05 percentage point, or $0.5 \%$. However, the percent of families below poverty would slightly decrease by 0.02 percentage points, or $0.08 \%$. While simulated impacts on poverty are lower than those experienced on average for other cities imposing living wage laws as discussed above, this is not inconsistent with the CPS estimates. The poverty thresholds used in the simulations are those reported by the New York City Center for Economic Opportunity (2011), which are higher than the federally reported poverty measures used in the CPS estimates.

\section{Income-Support and Other Programs}

We next turn to the consequences of the earnings changes for income-support and other programs. For Medicaid and SNAP, there is a clear predicted relationship whereby eligibility or benefits decrease as earnings increase. However, for the EITC, benefits initially rise as earnings increase over some range, then remain flat, and eventually decrease. So, for families affected by the living wage EITC benefits may decline or increase depending on family income and the effects of the living wage.

Table 9 shows the aggregate impacts on eligibility and potential benefit levels for New York City families when the effects of the proposed living wage are simulated. The simulations show declines in EITC payments, and in eligibility for and benefits from SNAP, but an increase in the percentage eligible 
for Medicaid. ${ }^{28}$ Not surprisingly, boroughs with a higher percentage of low-wage workers covered (e.g., Staten Island) are projected to experience greater changes in eligibility and benefit levels, and boroughs with a lower percentage of low-wage workers covered (e.g., Manhattan) are expected to have smaller changes. With respect to the EITC and SNAP, these conclusions imply that where a living wage law has the potential to deliver the most benefit because wages are lower, the earnings gains are likely to be more strongly offset because of declines in income from or eligibility for government assistance.

Finally, Table 9 reports the changes in earnings and benefit amounts that are implied by simulating the impact of the living wage. Based on the simulated effects, family earnings would increase by approximately $\$ 11.6$ million. Referring back to Table 7 , these increases come from the approximately 34,000 workers who experience a wage increase, while approximately 6,000 workers experience reduced earnings due to disemployment. SNAP benefits decline only slightly, while EITC benefits would decline by approximately $\$ 4.6$ million, offsetting over one third of the income gains.

\section{Conclusions}

We project the effects of a prospective living wage law in New York City, a type of exercise that has been fairly common in recent decades and shares many features with prospective evaluations of other proposed policies. Longitudinal estimation of living wages implemented in some cities can be used to estimate effects based on historical experience, but may fail to capture unique features of a specific labor market or policy proposal. Conversely, ex ante simulations absent evidence from this historical experience are too dependent on assumptions about behavioral responses. We therefore argue that the methods must be used together. In addition, newly-available administrative labor market data, as well as detailed information on where people live and work in the ACS, increase the scope for basing these kinds of studies on a very accurate and complete empirical description of the relevant labor market. This paper

\footnotetext{
${ }^{28}$ Because the simulations assume that individuals who continue employment at the living wage will receive an hourly wage of $\$ 10$, we implicitly assume that health benefits are provided. If we were to assume that wages would increase to $\$ 11.50$ per hour because health benefits were not provided, the percent of families eligible for Medicaid benefits would decrease. Offsetting this is the possibility that some employers would stop offering health insurance as a result of the wage floor. Note that the Medicaid income thresholds are higher than those for the other programs, especially for families with infants and young children. This may be one explanation for why we see a slight increase in Medicaid eligibility and small decreases in the other programs.
} 
demonstrates how we use these methods and data to study the proposed living wage law, and argues that these kinds of prospective evaluations should use these mixed methods and new data sources.

The key point of the paper is its demonstration of methods and uses of data, rather than the specific conclusions, both because research on the actual effects of laws is ultimately how social science evaluates policy, and the actual law implemented could end up differing from the one we studied. ${ }^{29}$ For the record, nonetheless, the longitudinal evidence points to living wages generating both winners and losers - the former those who get higher wages, and the latter those who become jobless. This evidence to some extent updates earlier research, although changes in geographic classifications in the CPS data pose challenges in updating the evidence to the present.

These estimated wage and employment effects, along with the administrative and ACS data, are used in the simulations for New York City, in large part to assess the likely distributional effects of the proposed living wage. The predicted distributional effects are quite modest, suggesting that the effect of living wages is primarily to shift earnings from some low-wage, low-skill workers to others. There is a net earnings gain to affected workers, but a sizable share of it (more than one-third) would likely be offset by lower EITC benefits.

Finally, the larger report (Charles Rivers Associates, 2011), of which our labor market research was one component, also studied how the real estate market in New York City was likely to be affected. The real estate analysis suggested potentially quite adverse effects on real estate development in New York City owing to particular features of the proposal we analyzed. Because the two markets are closely related, were these adverse effects on real estate development to occur, the labor market impacts could be worse than the relatively modest impacts suggested by our labor market analysis. The effects of living wage laws via effects on real estate markets have been largely unexplored in past research.

\footnotetext{
${ }^{29}$ In January 2012, it was announced that the proposal would be amended to exclude coverage of tenants, recipients of as-of-right financial assistance, certain types of projects and sectors, and generally to restrict the applicability of the wage mandates. At the time of this draft, the revised legislation has not been introduced.
} 


\section{References}

Adams, Scott, and David Neumark. 2004a. "The Economic Effects of Living Wages: A Provisional Review." Urban Affairs Review, Vol. 40, No. 2, November, pp. 210-45.

Adams, Scott, and David Neumark. 2004b. "A Decade of Living Wages: What Have We Learned?" California Economic Policy, Vol. 1, No. 1, July. San Francisco: Public Policy Institute of California.

Adams, Scott, and David Neumark. 2005a. "When Do Living Wages Bite?” Industrial Relations, Vol. 44, No. 1, January, pp. 164-192.

Adams, Scott, and David Neumark. 2005b. "Living Wage Effects: New and Improved Evidence." Economic Development Quarterly, pp. 80-102.

Blank, Rebecca M. 2002. "Evaluating Welfare Reform in the United States." Journal of Economic Literature, Vol. 40, No. 4, December, pp. 1105-66.

Brenner, Mark D., Jeannette Wicks-Lim, and Robert Pollin. 2002. "Measuring the Impact of Living Wage Laws: A Critical Appraisal of David Neumark's "How Living Wage Laws Affect Low-Wage Workers and Low-Income families." Political Economy Research Institute Working Paper No. 43. Amherst, MA: Political Economy Research Institute.

Cervero, Roberto. 2002. "Reverse Commuting and Job Access in the United States." Unpublished paper, University of California, Berkeley.

Charles Rivers Associates. 2011. "The Economic Impacts on New York City of the Proposed Living Wage Mandate." Available at

http://www.nycedc.com/NewsPublications/Studies/Documents/CombinedReportLivingWageImpacts.pdf (viewed December 13, 2011).

Fairris, David, and Leon Fernandez Bujanda. 2008. "The Dissipation of Minimum Wage Gains for Workers through Labor-Labor Substitution: Evidence from the Los Angeles Living Wage Ordinance." Southern Economic Journal, Vol. 75, No. 2, pp. 473-96.

Fairris, David, and Michael Reich. 2005. "The Impacts of Living Wage Policies: Introduction to the Special Issue.” Industrial Relations, Vol. 44, No. 1, January, pp. 1-13.

Fairris, David, David Runsten, Carolina Briones, and Jessica Goodheart. 2005. "Examining the Evidence: The Impact of the Los Angeles Living Wage Ordinance on Workers and Businesses." Los Angeles: Los Angeles Alliance for a New Economy.

Frey, William H., Wilson, Jill H., Berube, Alan, and Singer, Audrey. 2004. “Tracking Metropolitan America into the $21^{\text {st }}$ Century: A Field Guide to the New Metropolitan and Micropolitan Definitions.” Washington DC: The Brookings Institution Metropolitan Policy Program.

Groshen, Erica L. 1991. "The Structure of the Female/Male Wage Differential: Is It Who You Are, What You Do, or Where You Work?" Journal of Human Resources, Vol. 26, No. 3, Summer, pp. 457-72.

Holzer, Harry J. 2008. “Living Wage Laws: How Much Do (Can) They Matter?” Discussion Paper, Brookings Institution Metropolitan Policy Program, Washington, DC, December.

Lester, T. William, and Ken Jacobs. 2010. "Creating Good Jobs in Our Communities: How Higher Wage Standards Affect Economic Development and Employment." Center for American Progress Action Fund, Washington, D.C. 
Luce, Stephanie. 2004. Fighting for a Living Wage. Ithaca: Cornell University Press.

Neumark, David, and Scott Adams. 2003a. "Do Living Wage Ordinances Help Reduce Urban Poverty?" Journal of Human Resources, pp. 490-521.

Neumark, David, and Scott Adams. 2003b. "Detecting Effects of Living Wage Laws." Industrial Relations, Vol. 42, No. 4, October, pp. 531-64.

Neumark, David, Mark Schweitzer, and William Wascher. 2005. "The Effects of Minimum Wages on the Distribution of Family Incomes: A Nonparametric Analysis." Journal of Human Resources, Vol. 40, No. 4, Fall, pp. 867-94.

Neumark, David, and William L. Wascher. 2008. Minimum Wages. Cambridge, MA: MIT Press.

New York Center for Economic Opportunity. 2011. "Policy Affects Poverty: The CEO Poverty Measure, 2005-2009.” Working Paper, March 2011, Available at:

http://www.nyc.gov/html/ceo/downloads/pdf/poverty_measure_2011.pdf (viewed March 22, 2011).

New York City Department of Finance. 2011. Annual Report on Tax Expenditures Fiscal Year 2011, February. Available at: http://www.nyc.gov/html/dof/html/pdf/11pdf/ter_2011_final.pdf(viewed February 15, 2012).

New York City Economic Development Corporation. 2012. Annual Investment Projects Report Fiscal Year 2011, January. Available at: http://www.nycedc.com/about-nycedc/financial-public-documents (viewed February 15, 2012).

Pollin, Robert, Mark Brenner, Jeannette Wicks-Lim, and Stephanie Luce. 2008. A Measure of Fairness: The Economics of Living Wages and Minimum Wages in the United States. Ithaca, NY: ILR Press.

Pollin, Robert, and Stephanie Luce. 1998. The Living Wage: Building a Fair Economy. New York: The New Press.

Sander, Richard H., and E. Douglass Williams. 2005. "Santa Monica's Minimum Wage: Assessing the Living Wage Movement's New Frontier.” Economic Development Quarterly, Vol. 19, No. 1, February, pp. 25-44.

Tolley, George, Peter Bernstein, and Michael Lesage. 1999. "Economic Analysis of a Living Wage Ordinance.” Employment Policies Institute, Washington, D.C.

Wu, Ximing, Jeffrey M. Perloff, and Amos Golan. 2006. "Effects of Government Policies on Urban and Rural Income Inequality." Review of Income and Wealth, Vol. 52, No. 2, June, pp. 213-35. 
Table 1: The 52 Cities in the Analysis Sample, and their 39 MSAs/CMSAs

\begin{tabular}{|c|c|c|c|}
\hline MSA/CMSA & City & MSA/CMSA & City \\
\hline Albuquerque, NM MSA & Albuquerque & Milwaukee-Racine, WI CMSA & Milwaukee \\
\hline Atlanta, GA MSA & Atlanta & Minneapolis-St. Paul, MN-WI MSA & Minneapolis \\
\hline Boise City, ID MSA & Boise & Minneapolis-St. Paul, MN-WI MSA & St. Paul \\
\hline $\begin{array}{l}\text { Boston-Worcester-Lawrence, MA-NH- } \\
\text { ME-CT CMSA }\end{array}$ & Boston & $\begin{array}{l}\text { New York-Northern New Jersey-Long } \\
\text { Island, NY-NJ-CT-PA CMSA }\end{array}$ & Newark \\
\hline $\begin{array}{l}\text { Charlotte-Gastonia-Rock Hill, NC-SC } \\
\text { MSA }\end{array}$ & Charlotte & $\begin{array}{l}\text { New York-Northern New Jersey-Long } \\
\text { Island, NY-NJ-CT-PA CMSA }\end{array}$ & New York \\
\hline $\begin{array}{l}\text { Chicago-Gary-Kenosha, IL-IN-WI } \\
\text { CMSA }\end{array}$ & Chicago & Oklahoma City, OK MSA & Oklahoma City \\
\hline $\begin{array}{l}\text { Cincinnati-Hamilton, OH-KY-IN } \\
\text { CMSA }\end{array}$ & Cincinnati & Omaha, NE-IA MSA & Omaha \\
\hline Cleveland-Akron, OH CMSA & Cleveland & Orlando, FL MSA & Orlando \\
\hline Columbus, OH MSA & Columbus & $\begin{array}{l}\text { Philadelphia-Wilmington-Atlantic City, } \\
\text { PA-NJ-DE-MD CMSA }\end{array}$ & Philadelphia \\
\hline Dallas-Fort Worth, TX CMSA & Dallas & Phoenix-Mesa, AZ MSA & Phoenix \\
\hline Dallas-Fort Worth, TX CMSA & Fort Worth & Phoenix-Mesa, AZ MSA & Mesa \\
\hline Dallas-Fort Worth, TX CMSA & Arlington & Pittsburgh, PA MSA & Pittsburgh \\
\hline Denver-Boulder-Greeley, CO CMSA & Denver & Portland-Salem, OR-WA CMSA & Portland \\
\hline Denver-Boulder-Greeley, CO CMSA & Aurora & $\begin{array}{l}\text { Providence-Fall River-Warwick, RI- } \\
\text { MA MSA }\end{array}$ & Providence \\
\hline Detroit-Ann Arbor-Flint, MI CMSA & Detroit & Raleigh-Durham-Chapel Hill, NC MSA & Raleigh \\
\hline $\begin{array}{l}\text { Grand Rapids-Muskegon-Holland, MI } \\
\text { MSA }\end{array}$ & Grand Rapids & Sacramento-Yolo, CA CMSA & Sacramento \\
\hline Honolulu, HI MSA & Honolulu & Salt Lake City-Ogden, UT MSA & Salt Lake City \\
\hline $\begin{array}{l}\text { Houston-Galveston-Brazoria, TX } \\
\text { CMSA }\end{array}$ & Houston & San Diego, CA MSA & San Diego \\
\hline Kansas City, MO-KS MSA & Kansas City & $\begin{array}{l}\text { San Francisco-Oakland-San Jose, CA } \\
\text { CMSA }\end{array}$ & Oakland \\
\hline Las Vegas, NV-AZ MSA & Las Vegas & $\begin{array}{l}\text { San Francisco-Oakland-San Jose, CA } \\
\text { CMSA }\end{array}$ & San Francisco \\
\hline $\begin{array}{l}\text { Los Angeles-Riverside-Orange County, } \\
\text { CA CMSA }\end{array}$ & Los Angeles & $\begin{array}{l}\text { San Francisco-Oakland-San Jose, CA } \\
\text { CMSA }\end{array}$ & San Jose \\
\hline $\begin{array}{l}\text { Los Angeles-Riverside-Orange County, } \\
\text { CA CMSA }\end{array}$ & Santa Ana & Seattle-Tacoma-Bremerton, WA CMSA & Seattle \\
\hline $\begin{array}{l}\text { Los Angeles-Riverside-Orange County, } \\
\text { CA CMSA }\end{array}$ & Anaheim & St. Louis, MO-IL MSA & St. Louis \\
\hline $\begin{array}{l}\text { Los Angeles-Riverside-Orange County, } \\
\text { CA CMSA }\end{array}$ & Long Beach & $\begin{array}{l}\text { Tampa-St. Petersburg-Clearwater, FL } \\
\text { MSA }\end{array}$ & Tampa \\
\hline $\begin{array}{l}\text { Los Angeles-Riverside-Orange County, } \\
\text { CA CMSA }\end{array}$ & Riverside & $\begin{array}{l}\text { Washington-Baltimore, DC-MD-VA- } \\
\text { WV CMSA }\end{array}$ & Baltimore \\
\hline Miami-Fort Lauderdale, FL CMSA & Miami & $\begin{array}{l}\text { Washington-Baltimore, DC-MD-VA- } \\
\text { WV CMSA }\end{array}$ & Washington \\
\hline
\end{tabular}


Table 2: Estimated Effects of Living Wages on Log Wages and Employment, Lowest Decile of Wage Distribution or Predicted Wage Distribution (for Employment), Living Wages Defined at MSA/PMSA Level,

Prior Estimates and Re-estimations for 1996-2002

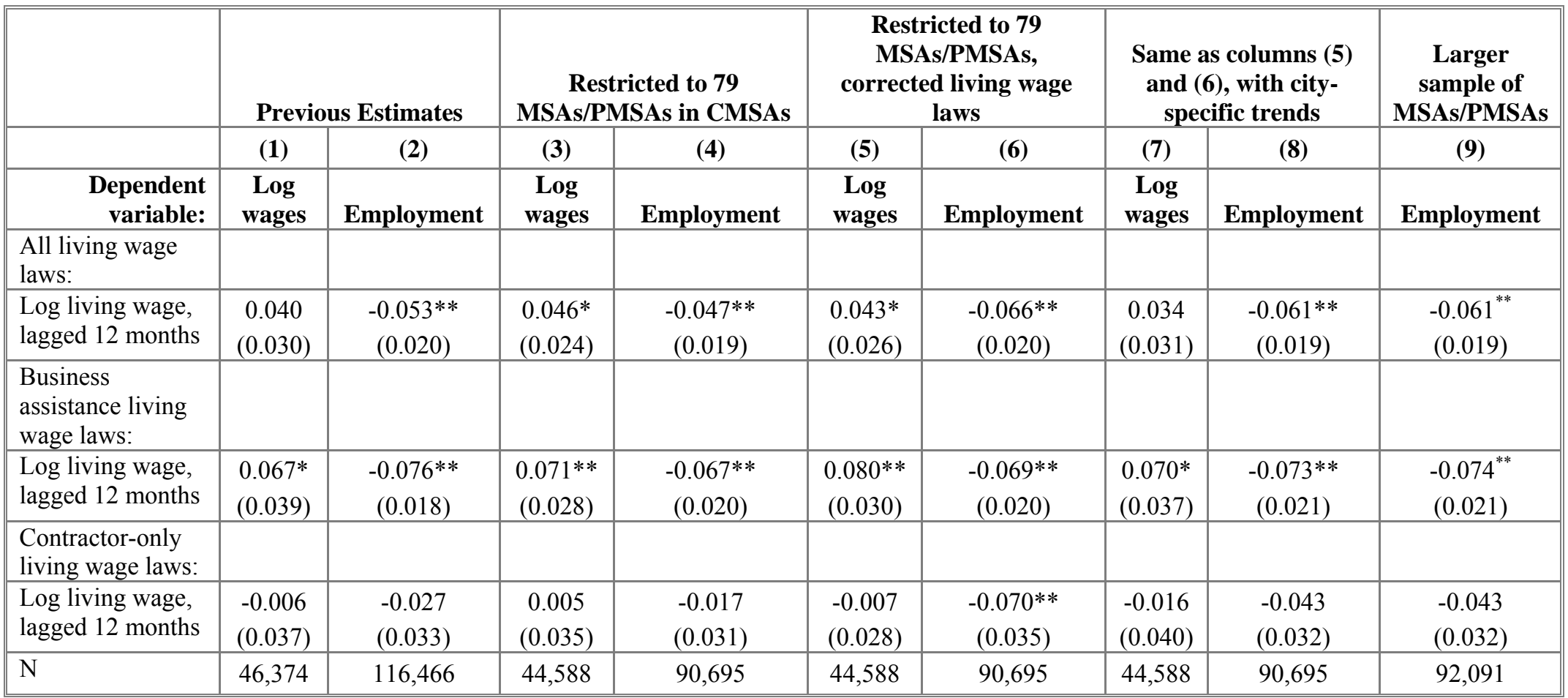

The estimates in columns (1) and (2) are from Adams and Neumark (2005b, Tables 2 and 4). The data on labor market outcomes and other workerrelated characteristics come from the Current Population Survey (CPS) monthly Outgoing Rotation Group files (ORGs/MORGs), from January 1996 through December 2002. Only observations on city-month or city-year cells with 25 or more observations are retained. The regressions include controls for city, year, month, minimum wages, and other individual-level controls. All specifications also allow differential linear time trends for cities passing or not passing living wage laws, or passing different types of laws, except columns (7) and (8). The entries in the first row are from a specification with a single living wage variable, and the entries in the second and third rows are from a specification that interacts the living wage variable with dummy variables for the type of living wage. The MSAs/PMSAs beginning in columns (3)-(4) are the MSAs and PMSAs that constitute the 39 CMSAs that we can track for the entire sample period and that meet the data sufficiency requirement ( 25 valid wage observations per MSA/PMSA and month). The list of these 79 MSAs/PMSAs used in columns (3)-(6) is available from the authors upon request. There are 86 MSAs/PMSAs in column (9), where we do not impose the same data sufficiency requirement on the employment and wage samples. Estimates are weighted by individual sample weights. " ${ }^{* *}$ ( $\left({ }^{*}\right.$ ) ) superscript indicates estimate is statistically significant at five-percent (ten-percent) level. Reported standard errors are robust to nonindependence (and heteroscedasticity) within city cells. 
Table 3: Estimated Effects of Living Wages on Log Wages and Employment,

Lowest Decile of Wage Distribution or Predicted Wage Distribution (for Employment)

\begin{tabular}{|c|c|c|c|c|c|c|c|c|}
\hline & \multicolumn{2}{|c|}{$\begin{array}{l}\text { “Baseline” estimates, } \\
\text { Table 2, columns (7) and } \\
\text { (8), 1996-2002 }\end{array}$} & \multicolumn{2}{|c|}{$\begin{array}{c}\text { Living wage variables } \\
\text { aggregated to CMSA level, } \\
1996-2009\end{array}$} & \multicolumn{2}{|c|}{$\begin{array}{c}\text { Living wage variables } \\
\text { aggregated to CMSA level, } \\
1996-2002\end{array}$} & \multicolumn{2}{|c|}{$\begin{array}{l}\text { Living wages defined at } \\
\text { MSA/PMSA level, 1996- } \\
2004\end{array}$} \\
\hline & (1) & (2) & (3) & (4) & (5) & (6) & (7) & (8) \\
\hline $\begin{array}{r}\text { Dependent } \\
\text { variable: }\end{array}$ & Log wages & Employment & Log wages & Employment & Log wages & Employment & Log wages & Employment \\
\hline $\begin{array}{l}\text { All living wage } \\
\text { laws: }\end{array}$ & & & & & & & & \\
\hline $\begin{array}{l}\text { Log living wage, } \\
\text { lagged } 12 \text { months }\end{array}$ & $\begin{array}{c}0.034 \\
(0.031) \\
\end{array}$ & $\begin{array}{c}-0.061 * * \\
(0.019)\end{array}$ & $\begin{array}{c}0.026 \\
(0.019)\end{array}$ & $\begin{array}{c}-0.019 * * \\
(0.009)\end{array}$ & $\begin{array}{c}0.009 \\
(0.036)\end{array}$ & $\begin{array}{l}-0.039 * \\
(0.021)\end{array}$ & $\begin{array}{c}0.037 \\
(0.034)\end{array}$ & $\begin{array}{c}-0.052 * * \\
(0.017)\end{array}$ \\
\hline $\begin{array}{l}\text { Business assistance } \\
\text { living wage laws: }\end{array}$ & & & & & & & & \\
\hline $\begin{array}{l}\text { Log living wage, } \\
\text { lagged } 12 \text { months }\end{array}$ & $\begin{array}{l}0.070 * \\
(0.037)\end{array}$ & $\begin{array}{c}-0.073 * * \\
(0.021)\end{array}$ & $\begin{array}{c}0.021 \\
(0.023)\end{array}$ & $\begin{array}{l}-0.005 \\
(0.012)\end{array}$ & $\begin{array}{c}0.025 \\
(0.042)\end{array}$ & $\begin{array}{l}-0.026 \\
(0.026)\end{array}$ & $\begin{array}{c}0.051 \\
(0.041)\end{array}$ & $\begin{array}{c}-0.055 * * \\
(0.023)\end{array}$ \\
\hline $\begin{array}{l}\text { Contractor-only } \\
\text { living wage laws: }\end{array}$ & & & & & & & & \\
\hline $\begin{array}{l}\text { Log living wage, } \\
\text { lagged } 12 \text { months }\end{array}$ & $\begin{array}{l}-0.016 \\
(0.040)\end{array}$ & $\begin{array}{l}-0.043 \\
(0.032)\end{array}$ & $\begin{array}{c}0.022 \\
(0.027)\end{array}$ & $\begin{array}{c}-0.029 * * \\
(0.014)\end{array}$ & $\begin{array}{l}-0.052 \\
(0.057)\end{array}$ & $\begin{array}{l}-0.053 \\
(0.035)\end{array}$ & $\begin{array}{c}0.020 \\
(0.056)\end{array}$ & $\begin{array}{c}-0.048 * * \\
(0.023)\end{array}$ \\
\hline $\mathrm{N}$ & 44,588 & 90,695 & 86,614 & 188,769 & 44,588 & 90,695 & 53,038 & 109,725 \\
\hline
\end{tabular}

Note: See notes to Table 2. '*' ('**') superscript indicates estimate is statistically significant at five-percent (ten-percent) level. All specifications have city-specific trends.

Table 4: Living Wage Errors in Boston CMSA Aggregation

\begin{tabular}{|c|c|c|c|c|c|}
\hline Year & $\begin{array}{l}\text { Obs. correctly assigned } \\
\text { living wage }\end{array}$ & $\begin{array}{c}\text { Obs. incorrectly } \\
\text { assigned living wage }\end{array}$ & $\begin{array}{c}\text { Total } \\
\text { obs. }\end{array}$ & $\begin{array}{c}\% \text { obs. wrongly assigned living } \\
\text { wage due to aggregation }\end{array}$ & $\begin{array}{c}\text { Avg. magnitude of } \\
\text { difference (\%) }\end{array}$ \\
\hline 1996 & 2,081 & - & 2,081 & $0 \%$ & $0 \%$ \\
\hline 1997 & 2,181 & - & 2,181 & $0 \%$ & $0 \%$ \\
\hline 1998 & 1,818 & 395 & 2,213 & $18 \%$ & $11 \%$ \\
\hline 1999 & 1,482 & 838 & 2,320 & $36 \%$ & $22 \%$ \\
\hline 2000 & 1,528 & 863 & 2,391 & $36 \%$ & $21 \%$ \\
\hline 2001 & 1,452 & 1,089 & 2,541 & $43 \%$ & $28 \%$ \\
\hline 2002 & 1,433 & 1,354 & 2,787 & $49 \%$ & $40 \%$ \\
\hline
\end{tabular}

The Boston CMSA is the "Boston-Cambridge-Quincy, MA-NH CMSA." The Boston CMSA is composed of six MSAs/PMSAs: Boston, MA-NH PMSA; Lowell, MA-NH PMSA; Manchester, NH PMSA; Nashua, NH PMSA; Portsmouth-Rochester, NH-ME PMSA; and Worcester, MA-CT PMSA. 
Table 5: Estimated Effects of Living Wages on Probability that Family is Poor, Prior Estimates and Re-estimations

\begin{tabular}{|c|c|c|c|c|c|c|}
\hline & 1995-2001 & \multicolumn{2}{|c|}{$\begin{array}{c}\text { Restricted to } 79 \text { MSAs/PMSAs, } \\
\text { corrected living wage laws, } \\
1995-2001\end{array}$} & $\begin{array}{c}\text { Living wage variables } \\
\text { aggregated to CMSA level, } \\
\text { 1995-2001 }\end{array}$ & $\begin{array}{l}\text { Living wage variables } \\
\text { aggregated to CMSA } \\
\text { level, 1995-2009 }\end{array}$ & $\begin{array}{l}\text { Column (3) } \\
\text { updated, } \\
\text { 1995-2003 }\end{array}$ \\
\hline & $\begin{array}{l}\text { restricted } \\
\text { trends }\end{array}$ & $\begin{array}{c}\text { Restricted } \\
\text { trends }\end{array}$ & City-specific trends & $\begin{array}{l}\text { City-specific } \\
\text { trends }\end{array}$ & City-specific trends & $\begin{array}{c}\text { City-specific } \\
\text { trends }\end{array}$ \\
\hline & (1) & (2) & (3) & (4) & (5) & (6) \\
\hline Sample mean & & 0.179 & 0.179 & 0.178 & 0.182 & 0.181 \\
\hline \multicolumn{7}{|c|}{ All living wage laws: } \\
\hline $\begin{array}{l}\text { Log living wage, } \\
\text { lagged } 12 \text { months }\end{array}$ & $\begin{array}{l}-0.035^{* *} \\
(0.013)\end{array}$ & $\begin{array}{l}-0.024 \\
(0.017)\end{array}$ & $\begin{array}{l}-0.019 \\
(0.016)\end{array}$ & $\begin{array}{c}-0.045^{* *} \\
(0.017)\end{array}$ & $\begin{array}{l}-0.001 \\
(0.009)\end{array}$ & $\begin{array}{l}-0.008 \\
(0.016)\end{array}$ \\
\hline \multicolumn{7}{|l|}{$\begin{array}{l}\text { Business assistance } \\
\text { living wage laws: }\end{array}$} \\
\hline $\begin{array}{l}\text { Log living wage, } \\
\text { lagged } 12 \text { months }\end{array}$ & $\begin{array}{l}-0.024^{*} \\
(0.013)\end{array}$ & $\begin{array}{l}-0.027 \\
(0.022)\end{array}$ & $\begin{array}{l}-0.041 * \\
(0.021)\end{array}$ & $\begin{array}{l}-0.069 * * \\
(0.022)\end{array}$ & $\begin{array}{l}-0.024 * * \\
(0.012)\end{array}$ & $\begin{array}{l}-0.035 \\
(0.022)\end{array}$ \\
\hline \multicolumn{7}{|l|}{$\begin{array}{l}\text { Contractor-only } \\
\text { living wage laws: }\end{array}$} \\
\hline $\begin{array}{l}\text { Log living wage, } \\
\text { lagged } 12 \text { months }\end{array}$ & $\begin{array}{l}-0.038 \\
(0.025)\end{array}$ & $\begin{array}{l}-0.012 \\
(0.024)\end{array}$ & $\begin{array}{c}0.012 \\
(0.023)\end{array}$ & $\begin{array}{l}-0.003 \\
(0.026)\end{array}$ & $\begin{array}{c}0.017 \\
(0.011)\end{array}$ & $\begin{array}{c}0.021 \\
(0.020)\end{array}$ \\
\hline $\mathrm{N}$ & 142,421 & 115,818 & 115,818 & 117,658 & 308,008 & 157,048 \\
\hline
\end{tabular}

See notes to Table 2. The March ASEC files are used for these estimates. Poverty is defined in terms of total income. The estimates in column (1) are from Adams and Neumark (2005b, Table 5). The regressions include controls for city, year, and minimum wages. Estimates are weighted by family sample weights. '*' ('**') superscript indicates estimate is statistically significant at five-percent (ten-percent) level. 
Table 6: Estimated Effects of Living Wages on Income Support and Program Participation, 1995-2003

\begin{tabular}{|c|c|c|c|c|c|c|c|}
\hline & \multicolumn{2}{|c|}{$\begin{array}{c}\text { Public } \\
\text { assistance/welfare }\end{array}$} & \multicolumn{2}{|c|}{ Food stamps } & \multicolumn{3}{|c|}{ Any benefits from: } \\
\hline & $\begin{array}{c}\begin{array}{c}\text { Value } \\
\text { of } \\
\text { benefits }\end{array} \\
\end{array}$ & $\begin{array}{c}\text { Any } \\
\text { benefits }\end{array}$ & $\begin{array}{c}\begin{array}{c}\text { Value of } \\
\text { food } \\
\text { stamps }\end{array} \\
\end{array}$ & $\begin{array}{c}\text { Any } \\
\text { benefits }\end{array}$ & $\begin{array}{c}\text { Free or } \\
\text { reduced- } \\
\text { price hot } \\
\text { lunch }\end{array}$ & $\begin{array}{c}\text { Public } \\
\text { housing }\end{array}$ & $\begin{array}{c}\text { Energy } \\
\text { assistance }\end{array}$ \\
\hline & (1) & (2) & (3) & (4) & (5) & (6) & (7) \\
\hline Sample mean & 145.53 & 0.037 & 154.93 & 0.079 & 0.103 & 0.030 & 0.021 \\
\hline \multicolumn{8}{|c|}{ All living wage laws: } \\
\hline $\begin{array}{l}\text { Log living wage, } \\
\text { lagged } 12 \text { months }\end{array}$ & $\begin{array}{l}-14.857 \\
(56.722)\end{array}$ & $\begin{array}{c}0.001 \\
(0.011) \\
\end{array}$ & $\begin{array}{l}-12.479 \\
(40.266)\end{array}$ & $\begin{array}{c}0.007 \\
(0.015)\end{array}$ & $\begin{array}{l}-0.019 * \\
(0.012)\end{array}$ & $\begin{array}{c}-0.017 * * \\
(0.008)\end{array}$ & $\begin{array}{l}-0.009 \\
(0.007) \\
\end{array}$ \\
\hline \multicolumn{8}{|l|}{$\begin{array}{l}\text { Business assistance } \\
\text { living wage laws: }\end{array}$} \\
\hline $\begin{array}{l}\text { Log living wage, } \\
\text { lagged } 12 \text { months }\end{array}$ & $\begin{array}{l}-96.483 \\
(67.362)\end{array}$ & $\begin{array}{c}-0.025^{* *} \\
(0.011)\end{array}$ & $\begin{array}{l}-23.055 \\
(48.909)\end{array}$ & $\begin{array}{l}-0.004 \\
(0.019)\end{array}$ & $\begin{array}{l}-0.024 \\
(0.017)\end{array}$ & $\begin{array}{c}-0.032 * * \\
(0.013)\end{array}$ & $\begin{array}{c}-0.020^{* *} \\
(0.008)\end{array}$ \\
\hline \multicolumn{8}{|l|}{$\begin{array}{l}\text { Contractor-only } \\
\text { living wage laws : }\end{array}$} \\
\hline $\begin{array}{l}\text { Log living wage, } \\
\text { lagged } 12 \text { months }\end{array}$ & $\begin{array}{c}70.999 \\
(71.827)\end{array}$ & $\begin{array}{l}0.028^{* *} \\
(0.014)\end{array}$ & $\begin{array}{l}-1.355 \\
(59.606)\end{array}$ & $\begin{array}{c}0.018 \\
(0.021)\end{array}$ & $\begin{array}{l}-0.014 \\
(0.013)\end{array}$ & $\begin{array}{l}-0.002 \\
(0.008)\end{array}$ & $\begin{array}{c}0.003 \\
(0.009)\end{array}$ \\
\hline $\mathrm{N}$ & 157,048 & 157,048 & 157,048 & 157,048 & 157,048 & 157,048 & 157,048 \\
\hline
\end{tabular}

See notes to Tables 2 and 5. All specifications have city-specific trends. The benefits variables are annual. The specifications for receipt of benefits are linear probability models. ' $*$ ' ('**') superscript indicates estimate is statistically significant at five-percent (ten-percent) level. 
Figure 1: Distribution of Wages Before and After Implementation of a $\$ 10$ Living Wage Law (sites receiving $\$ 100,000$ or more of assistance in at least one year)

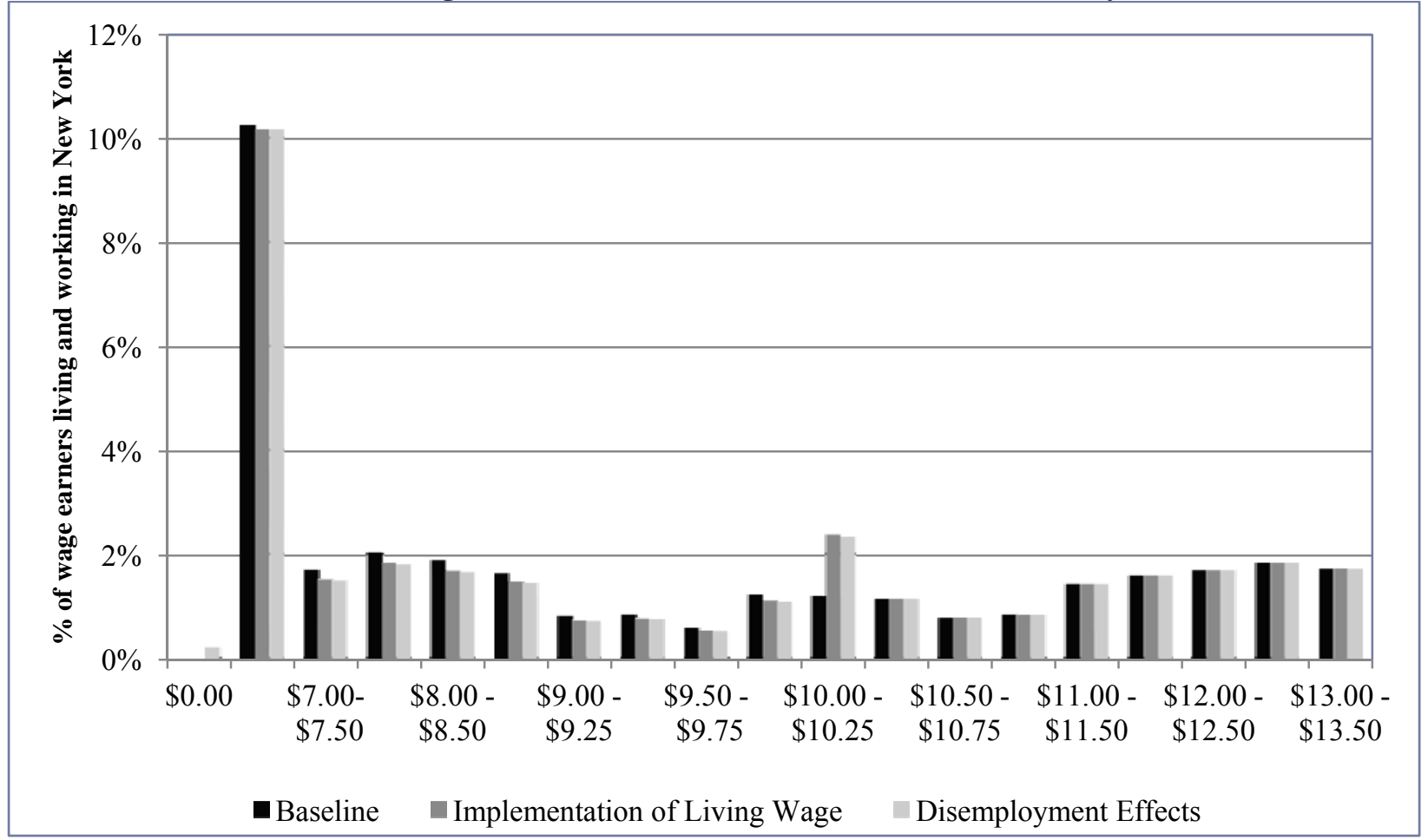

Figure 2: Distribution of Wages Before and After Implementation of a \$10 Living Wage Law

Retail Trade Industry, by Borough

(sites receiving $\mathbf{\$ 1 0 0 , 0 0 0}$ or more of assistance in at least one year)

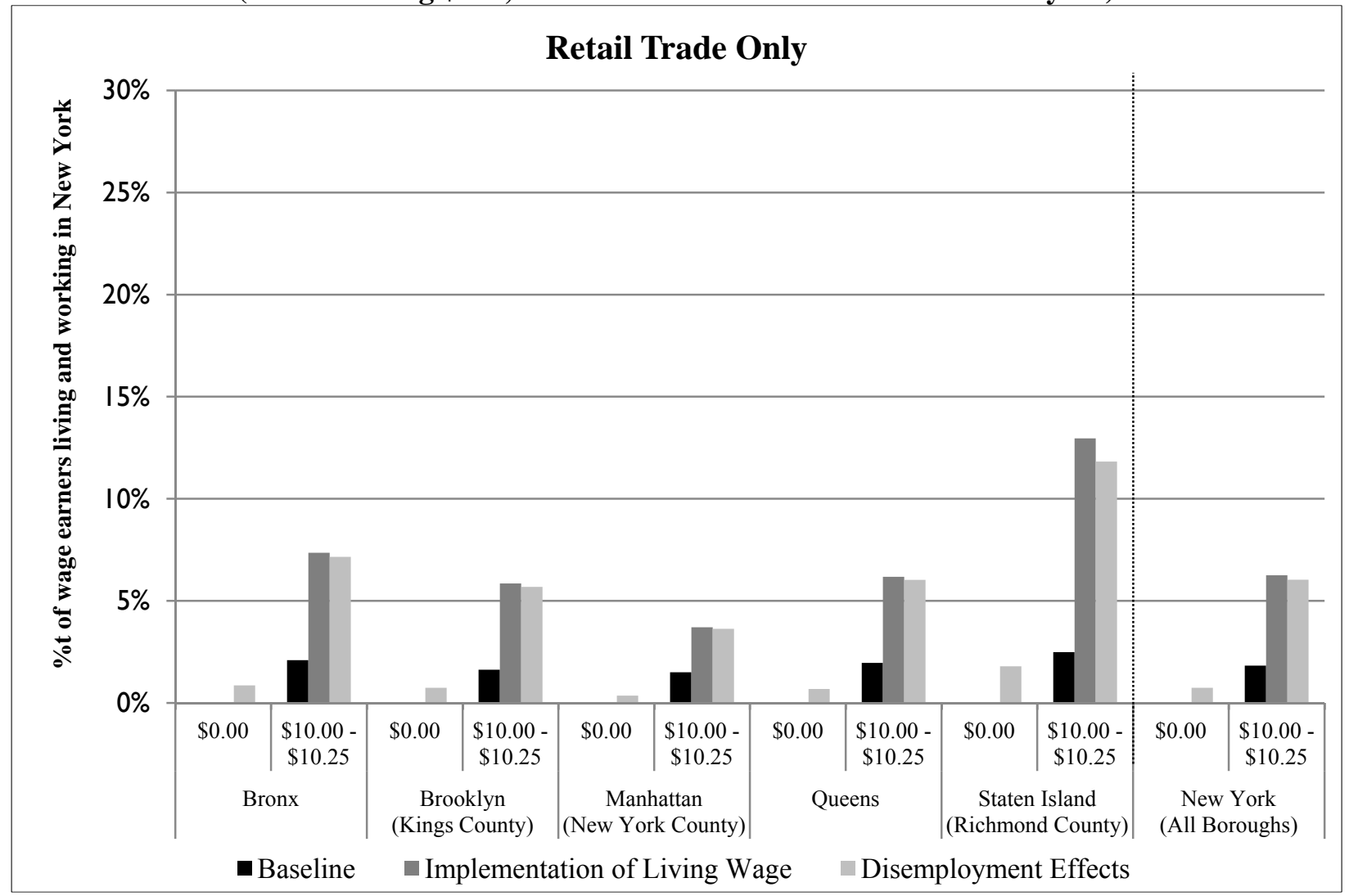


Table 7: Wage and Employment Changes, Overall, by Borough, and Outside New York City (based on sites receiving $\mathbf{\$ 1 0 0 , 0 0 0}$ or more of assistance in at least one year)

\begin{tabular}{|c|c|c|c|c|c|c|c|c|c|c|}
\hline & $\begin{array}{c}\text { Percent of } \\
\text { workers earning } \\
<\$ 10 \text { per hour at } \\
\text { covered sites }\end{array}$ & $\begin{array}{c}\text { Percent } \\
\text { affected } \\
\text { relative to } \\
\text { workforce }\end{array}$ & $\begin{array}{c}\text { Average } \\
\text { percentage } \\
\text { wage } \\
\text { increase } \\
\end{array}$ & $\begin{array}{c}\text { Percent of } \\
\text { workforce } \\
\text { experiencing } \\
\text { job loss } \\
\end{array}$ & $\begin{array}{c}\text { Number of } \\
\text { individuals } \\
\text { with wage } \\
\text { increases }\end{array}$ & $\begin{array}{l}\text { Number of } \\
\text { individuals } \\
\text { experiencing } \\
\text { job loss }\end{array}$ & $\begin{array}{l}\text { Average } \\
\text { wage } \\
\text { change } \\
\text { (all) }\end{array}$ & $\begin{array}{c}\text { Average } \\
\text { wage } \\
\text { increase }\end{array}$ & $\begin{array}{c}\text { Average } \\
\text { wage } \\
\text { before }\end{array}$ & $\begin{array}{c}\text { Average } \\
\text { wage } \\
\text { after }\end{array}$ \\
\hline New York City & $12.9 \%$ & $1.2 \%$ & $0.1 \%$ & $0.2 \%$ & 33,561 & 5,896 & $\$ 0.02$ & $\$ 1.67$ & $\$ 8.37$ & $\$ 8.39$ \\
\hline Bronx & $12.9 \%$ & $1.6 \%$ & $0.1 \%$ & $0.3 \%$ & 6,017 & 1,067 & $\$ 0.03$ & $\$ 1.70$ & $\$ 8.36$ & $\$ 8.39$ \\
\hline Brooklyn (Kings County) & $9.9 \%$ & $1.1 \%$ & $0.1 \%$ & $0.2 \%$ & 9,749 & 1,734 & $\$ 0.01$ & $\$ 1.64$ & $\$ 8.40$ & $\$ 8.41$ \\
\hline Manhattan (New York County) & $12.5 \%$ & $0.7 \%$ & $0.0 \%$ & $0.1 \%$ & 4,437 & 778 & $\$ 0.02$ & $\$ 1.68$ & $\$ 8.33$ & $\$ 8.35$ \\
\hline Queens & $13.5 \%$ & $1.4 \%$ & $0.1 \%$ & $0.2 \%$ & 10,815 & 1,845 & $\$ 0.02$ & $\$ 1.66$ & $\$ 8.36$ & $\$ 8.38$ \\
\hline $\begin{array}{l}\text { Staten Island } \\
\text { (Richmond County) }\end{array}$ & $31.3 \%$ & $1.5 \%$ & $0.1 \%$ & $0.3 \%$ & 2,543 & 472 & $\$ 0.02$ & $\$ 1.65$ & $\$ 8.46$ & $\$ 8.48$ \\
\hline Outside New York City & & & & & 2,820 & 490 & $\$ 0.01$ & $\$ 1.50$ & $\$ 8.54$ & $\$ 8.55$ \\
\hline
\end{tabular}


Figure 3: Distribution of Family Earnings Relative to the NYC CEO Poverty Threshold (based on sites receiving $\$ \mathbf{1 0 0 , 0 0 0}$ or more of assistance in at least one year)

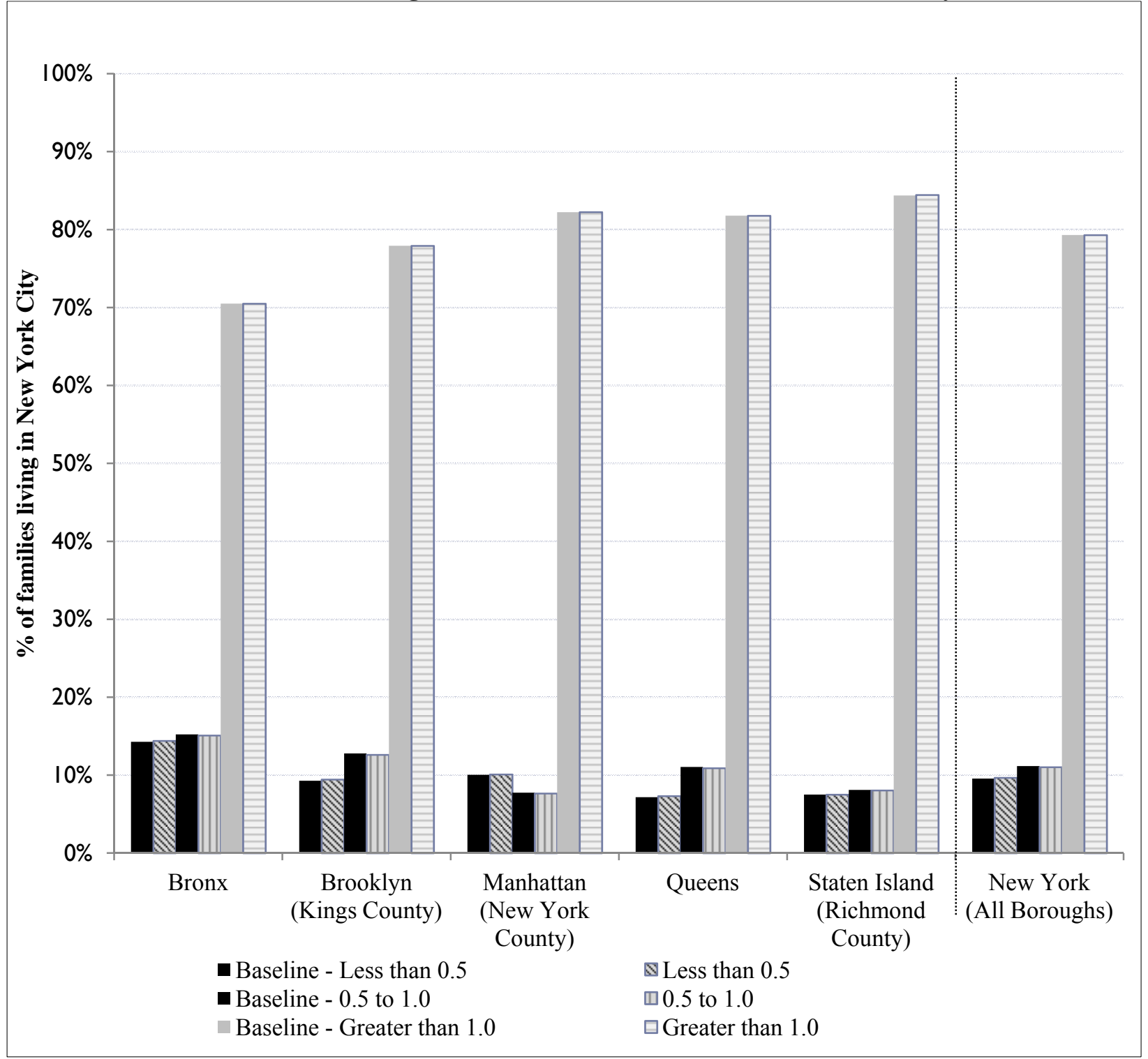


Table 8: Changes in Family Poverty Status, by Borough (based on sites receiving $\mathbf{\$ 1 0 0 , 0 0 0}$ or more of assistance in at least one year)

\begin{tabular}{|l|c|c|c|c||}
\hline & \multicolumn{2}{|c|}{ Families in extreme poverty } & \multicolumn{2}{c|}{ Families Below Poverty } \\
\hline & $\begin{array}{c}\text { Difference in } \\
\text { percentage } \\
\text { points }\end{array}$ & $\begin{array}{c}\text { Percentage } \\
\text { change }\end{array}$ & $\begin{array}{c}\text { Difference in } \\
\text { percentage } \\
\text { points }\end{array}$ & $\begin{array}{c}\text { Percentage } \\
\text { change }\end{array}$ \\
\hline New York City & $0.05 \%$ & $0.50 \%$ & $-0.02 \%$ & $-0.08 \%$ \\
\hline & & & & \\
\hline Bronx & $0.05 \%$ & $0.34 \%$ & $-0.01 \%$ & $-0.02 \%$ \\
\hline Brooklyn (Kings County) & $0.05 \%$ & $0.59 \%$ & $-0.01 \%$ & $-0.05 \%$ \\
\hline Manhattan (New York County) & $0.03 \%$ & $0.32 \%$ & $-0.02 \%$ & $-0.09 \%$ \\
\hline Queens & $0.07 \%$ & $0.99 \%$ & $-0.02 \%$ & $-0.09 \%$ \\
\hline Staten Island (Richmond County) & $-0.04 \%$ & $-0.47 \%$ & $-0.07 \%$ & $-0.44 \%$ \\
\hline
\end{tabular}

Table 9: Changes in Support Programs

(based on sites receiving $\mathbf{\$ 1 0 0 , 0 0 0}$ or more of assistance in at least one year)

\begin{tabular}{|c|c|c|c|c|c|}
\hline & & $\begin{array}{l}\text { Percent } \\
\text { change in } \\
\text { EITC } \\
\text { amount }\end{array}$ & $\begin{array}{c}\text { Percent } \\
\text { change in } \\
\text { number } \\
\text { Medicaid } \\
\text { eligible }\end{array}$ & $\begin{array}{c}\text { Percent } \\
\text { change in } \\
\text { number } \\
\text { SNAP } \\
\text { eligible }\end{array}$ & $\begin{array}{c}\text { Percent } \\
\text { change in } \\
\text { total } \\
\text { amount of } \\
\text { SNAP }\end{array}$ \\
\hline New York City & & $-0.45 \%$ & $0.21 \%$ & $-0.18 \%$ & $-0.11 \%$ \\
\hline Bronx & & $-0.49 \%$ & $0.12 \%$ & $-0.11 \%$ & $-0.07 \%$ \\
\hline Brooklyn (Kings County) & & $-0.44 \%$ & $0.20 \%$ & $-0.16 \%$ & $-0.10 \%$ \\
\hline Manhattan (New York County) & & $-0.45 \%$ & $0.16 \%$ & $-0.12 \%$ & $-0.08 \%$ \\
\hline Queens & & $-0.47 \%$ & $0.39 \%$ & $-0.29 \%$ & $-0.16 \%$ \\
\hline Staten Island (Richmond County) & & $-0.28 \%$ & $0.06 \%$ & $-0.45 \%$ & $-0.14 \%$ \\
\hline & $\begin{array}{c}\text { Change in } \\
\text { total } \\
\text { earnings }\end{array}$ & $\begin{array}{l}\text { Change in } \\
\text { EITC } \\
\text { amount }\end{array}$ & $\begin{array}{l}\text { Change in } \\
\text { number } \\
\text { Medicaid } \\
\text { eligible }\end{array}$ & $\begin{array}{c}\text { Change in } \\
\text { number } \\
\text { SNAP } \\
\text { eligible }\end{array}$ & $\begin{array}{c}\text { Change in } \\
\text { total } \\
\text { amount of } \\
\text { SNAP }\end{array}$ \\
\hline New York City & $\$ 11,614,097$ & $-\$ 4,639,732$ & 784 & -945 & $-\$ 198,478$ \\
\hline Bronx & $\$ 2,525,020$ & $-\$ 1,196,001$ & 100 & -114 & $-\$ 27,741$ \\
\hline Brooklyn (Kings County) & $\$ 2,818,007$ & $-\$ 1,517,036$ & 226 & -249 & $-\$ 63,228$ \\
\hline New York (Manhattan) & $\$ 1,567,378$ & $-\$ 613,921$ & 132 & -140 & $-\$ 28,573$ \\
\hline Queens & $\$ 4,679,903$ & $-\$ 1,204,460$ & 316 & -346 & $-\$ 68,554$ \\
\hline Staten Island (Richmond County) & $\$ 23,789$ & $-\$ 108,314$ & 10 & -96 & $-\$ 10,383$ \\
\hline
\end{tabular}

